\title{
Accountability of independent directors: Evidence from firms subject to securities litigation
}

\section{Citation}

Brochet, Francois, and Suraj Srinivasan. "Accountability of Independent Directors-Evidence from Firms Subject to Securities Litigation." Journal of Financial Economics 111, no. 2 (February 2014): 430-449.

\section{Published Version}

http://dx.doi.org/10.1016/j.jfineco.2013.10.013

\section{Permanent link}

http://nrs.harvard.edu/urn-3:HUL.InstRepos:29660918

\section{Terms of Use}

This article was downloaded from Harvard University's DASH repository, and is made available under the terms and conditions applicable to Open Access Policy Articles, as set forth at http:// nrs.harvard.edu/urn-3:HUL.InstRepos:dash.current.terms-of-use\#OAP

\section{Share Your Story}

The Harvard community has made this article openly available.

Please share how this access benefits you. Submit a story.

Accessibility 


\title{
Accountability of independent directors - \\ Evidence from firms subject to securities litigation
}

\author{
Francois Brochet \\ fbrochet@hbs.edu \\ Harvard Business School \\ Suraj Srinivasan \\ ssrinivasan@hbs.edu \\ Harvard Business School
}

June 2013

\begin{abstract}
We examine which independent directors are held accountable when investors sue firms for financial and disclosure related fraud. Investors can name independent directors as defendants in lawsuits, and they can vote against their re-election to express displeasure over the directors' ineffectiveness at monitoring managers. In a sample of securities class-action lawsuits from 1996 to 2010, about 11\% of independent directors are named as defendants. The likelihood of being named is greater for audit committee members and directors who sell stock during the class period. Named directors receive more negative recommendations from Institutional Shareholder Services (ISS), a proxy advisory firm, and significantly more negative votes from shareholders than directors in a benchmark sample. They are also more likely than other independent directors to leave sued firms. Overall, shareholders use litigation along with director elections and director retention to hold some independent directors more accountable than others when firms experience financial fraud.

JEL: G30; G34; J33; K22; M41.

We are grateful to many plaintiff and defense attorneys, D\&O insurance specialists, corporate general counsels, corporate directors, and Carol Bowie of Institutional Shareholder Services, who helped us understand the institutional features of securities class-action litigation and its consequences for independent directors. We also thank Jay Lorsch, Lena Goldberg, Paul Healy, Chris Noe, Krishna Palepu, Douglas Skinner, and workshop participants at Chinese University Hong Kong, Harvard Business School, George Washington University, Tilburg University, and the University of Southern California for their comments and suggestions. Lizzie Gomez and James Zeitler provided excellent research assistance.
\end{abstract}




\section{Accountability of independent directors - Evidence from firms subject to securities litigation}

We examine accountability of independent directors when firms experience litigation for corporate financial fraud. Shareholders have two publicly visible means for holding directors accountable - they can sue directors and they can vote against director re-election. We use the incidence of independent directors being named as defendants in securities class action lawsuits and shareholder votes against those directors to assess which directors are held accountable for the violations that lead to the lawsuits.

Independent directors named as defendants in securities lawsuits (hereafter named directors or named defendants) face the possibility of financial and reputational harm, lost time and emotional distress. ${ }^{1}$ Their personal financial liability from lawsuits is limited in the U.S. (Black, Cheffins, and Klausner, 2006a). But public pension fund plaintiffs did require personal settlement payments collectively amounting to \$13 million and \$24.75 million respectively from independent directors in high profile cases relating to the Enron and WorldCom scandals. These plaintiffs aimed to show that directors were accountable for corporate fraud (Office of the New York State Comptroller, 2005). Their efforts, combined with increased duties for independent directors mandated by the Sarbanes-Oxley Act (SOX) in 2002, have caused concern that directors' litigation risk has increased (Bebchuk, 2006; Laux, 2010; Steinberg, 2011).

\footnotetext{
${ }^{1}$ This quote by Toby Myerson, Partner. Paul, Weiss, Rifkind, Wharton \& Garrison LLP at Harvard Law School Symposium on Director Liability, 2005, quoted in Bebchuk (2006) reflects this concern: "Most people who consider acting as directors don't want to have their name in the caption of the lawsuit. They don't want to have to establish that they didn't do anything wrong. They don't want to have to be deposed and spend their time dealing with the litigation. Life is too short. People are busy; they have other things to do.”
} 
We expect director accountability to reflect the director's role in the irregularity, the severity of the problem, and nature of the plaintiff investors. Investors are likely to hold accountable those directors with greater roles in financial oversight and those that appear to have profited from fraud and name them as defendants. We test both suppositions. We identify audit committee directors as the ones with greater oversight over accounting and disclosure issues, and directors that sold shares as more likely to have profited from inside information. We also expect more independent directors to be named when the cases are more severe and with greater shareholder losses. Because Section 11 violations allow for a broader inclusion of defendants than Rule 10b-5 lawsuits, we expect a higher incidence of named directors in Section 11 lawsuits. $^{2}$ Finally, we expect institutional plaintiffs to be more likely to enforce accountability. Institutional investor plaintiffs are likely among the largest shareholders and have incentives to discipline directors who they may hold accountable for any misrepresentations.

Our sample consists of companies sued for violation of Section $10 \mathrm{~b}(5)$ or Section 11 of the Securities Acts between 1996 and 2010, whose information we collect from the ISS Securities Class Action Litigation database. When intersected with firms in the IRRC Directors database, we get a sample of 921 lawsuits filed against U.S. firms in the S\&P 1500. We find that, conditional on a company being sued, $11 \%$ of independent directors are named as defendants. We also find that the likelihood of being named is higher for independent directors who have served on the audit committee (54\% of named

\footnotetext{
${ }^{2}$ Section 11(a) of the Securities Act of 1933 intends to ensure accurate disclosure to investors during the offer and sale of securities. Rule 10b-5 of the Securities Exchange Act of 1934 pertains to companies listed in the secondary markets and requires accurate representations to existing investors.
} 
defendants), have sold shares during the class period (16\% of named defendants), or have been on the board for the entire class period. It's also higher when the lead plaintiff is an institutional investor and when the lawsuit is filed under Sec. 11.

Irrespective of litigation, shareholders can also hold directors accountable by voting against them. Recent research (Cai, Garner, and Walkling, 2009) finds that shareholder votes are significantly related to director performance and that boards act as if they respond, even if the economic magnitude of the negative votes is small. We expect shareholders to continue their accountability efforts towards named directors by voting against those directors' re-election. We find that Institutional Shareholder Services (ISS), the leading proxy advisor, and shareholders view named directors negatively. These directors have a greater percentage of withheld votes (5.47 \% greater) compared with directors in a matched sample of non-sued firms. The mean matched firm negative vote (5.03\%) is similar to the $5.73 \%$ negative vote for the average director documented in Cai, Garner, and Walkling (2009). The mean negative vote for named directors (10.50\%) is thus about twice that for matched firm directors and a benchmark from prior research. Non-named directors of sued firms have a modestly greater negative vote $(1.10 \%$ greater) than directors of non-sued firms.

Accountability can also be reflected in greater turnover for named directors. In our study, these directors are more likely to leave a sued company within two years of the lawsuit than other directors in the same firm and the matched sample. The marginal effect of being named on director turnover is $3.62 \%$, which implies a $30 \%$ higher rate than the unconditional probability of turnover in our sample. The propensity of named directors to leave the board is greater in lawsuits that are not dismissed (the settled cases) and for 
audit committee members. The likelihood of leaving increased for both named and other directors in sued firms after 2002 (post-SOX), which we use as a proxy for greater governance sensitivity.

Naming directors as defendants can also have economic implications for lawsuit outcomes. We expect a positive association between directors being named as defendants and the likelihood that a lawsuit will (i) not be dismissed, (ii) reach a settlement faster and (iii) settle for more, based on two non-mutually exclusive hypotheses. First, as the Enron and WorldCom cases suggest, independent directors can be named in more severe lawsuits. Second, plaintiffs' lawyers can strategically name independent directors as a negotiating tactic. Our regression results show that the likelihood of lawsuit dismissal decreases in the number of named directors with a marginal effect of $2.75 \%$, time to settlement is faster when more directors are named, and the settlement amount increases by about $9 \%$ for every named director after controlling for the severity of the alleged wrongdoing. Further analysis suggests that independent directors are targeted by plaintiffs employing more strategic negotiating tactics.

Prior literature (e.g., Srinivasan, 2005; Fich and Shivdasani, 2007) suggests that independent directors lose positions on other corporate boards when companies whose boards they serve on experience financial irregularities. These papers interpret the loss of other directorships as a reputational penalty. While these papers examine director reputation, we focus on director accountability. Examining which independent directors are held accountable helps in assessing directors' incentives to function as monitors. ${ }^{3}$

\footnotetext{
${ }^{3}$ We recognize that a lawsuit filed for securities law violation does not imply that a fraud actually occurred. Consistent with prior research, in the absence of a foolproof way to identify fraud and director intent, lawsuits provide a proxy of how investors perceive the director's role in monitoring.
} 
Regulatory efforts such as the SEC's proxy access initiative to allow greater shareholder say in director elections are motivated by the premise that shareholders will use their influence to improve firm governance. Bebchuk $(2005,2007)$ posits that voting reform is necessary to empower shareholders to hold directors accountable. Our findings suggest that shareholders already hold some independent directors accountable both through litigation and through director elections but at levels that appear to be of modest economic magnitudes.

Our paper extends the literature in several ways. We add to the scholarship on director litigation risk by examining which directors are named in lawsuits and the causes and consequences. Prior research has used all audit or compensation committee directors as potentially culpable for accounting or compensation irregularities (e.g., Srinivasan, 2005; Ertimur, Ferri and Maber, 2012). But since not all directors are likely to be held equally accountable, we identify responsibility more directly using directors singled out by the plaintiff investors.

We also identify cross sectional and time-series determinants of turnover and shareholder voting relating to directors in sued firms. These combined with supplemental findings on the effect of independent directors on settlements present a fuller picture of the mechanisms that shareholders have to hold directors accountable and which directors they hold accountable for financial fraud.

\section{Board Accountability for Corporate Fraud}

\subsection{Accountability through Securities Class Action Litigation}


Black, Cheffins, and Klausner (2006a) show that independent directors have been held personally financially responsible in securities litigation only occasionally—in only thirteen cases since 1980 has a director made a personal payment for settlement or for legal expenses. Financial costs for settlements, since suits rarely go to trial, are normally indemnified by the company or paid by director and officer (D\&O) insurance. However, financial risk to directors, while small, increases when a firm has inadequate D\&O coverage, when the D\&O insurance does not cover directors involved in fraud, and when a sued firm or its D\&O insurer becomes insolvent. Black, Cheffins, and Klausner (2006a) conclude that "the principal threats to outside directors who perform poorly are the time, aggravation, and potential harm to reputation that a lawsuit can entail, not direct financial loss" (p. 1056).

Fear of legal liability has long been perceived as deterring individuals from serving as directors (Romano, 1989; Sahlman, 1990, Alexander, 1991) and causing directors to be risk averse, thus reducing board effectiveness (Black, Cheffins, and Klausner, 2006a). These concerns have led to recommendations for greater protection of independent directors from securities lawsuits (Committee on Capital Markets Regulation, 2006). Black, Cheffins, and Klausner (2006b), however, conjecture that the litigation risk may be overstated, as only a subset of directors are named as defendants in securities lawsuits. They point out that no data exist on how often outside directors are named as defendants. Alexander (1991) posits that risk-averse people will assign greater weight to even low-likelihood events if the penalties are severe, as they can be if damages are assessed on independent directors. 
Prior papers (e.g., Fich and Shivdasani, 2007; Cai, Garner, and Walking, 2009) consider all directors of sued firms as affected by litigation. But we expect that not all directors are likely to be held equally accountable. Our interviews with both plaintiff and defense attorneys and with directors who have been sued suggest that costs in terms of time, distress, and money (however limited) arise mainly for directors named as defendants.

The Securities and Exchange Commission (SEC) requires companies to disclose any litigation against directors or director nominees in the previous ten years (up from five years before the new rules in 2009). The SEC expanded the list of reportable litigation to include proceedings related to federal or state securities laws, even if they were settled. The SEC considers this information material to an evaluation of "an individual's competence and integrity to serve as a director" (SEC 2009, pp. 36-37). The Proxy advisory services, ISS, Glass-Lewis, and Governance Metrics, track named defendants. Databases of directors and companies involved in litigation maintained by the proxy advisors and disclosure in proxy statements reduce the cost to investors to hold directors accountable.

Alexander (1991) suggests that plaintiffs include individual directors as defendants, as they are more risk averse than the entity defendants (company, auditors, underwriters, etc.) and therefore more amenable to settling, giving plaintiffs leverage in negotiations. This is especially true for independent directors compared with officers of the company, as the potential liability is significantly greater than the pay that independent directors receive for their work. ${ }^{4}$

\footnotetext{
${ }^{4}$ While investors sue the named defendants, in practice the plaintiff law firms drive class action lawsuits. Since the litigation is on behalf of the firm's investors, we believe it is a relevant mechanism to express
} 
Armour, Black, Cheffins, and Nolan (2009) support this reasoning and argue that independent directors are named as defendants to pressure the board to settle and to facilitate gathering of evidence through discovery but not necessarily because they are likely to be found liable. In our interviews, plaintiff attorneys confirm that named directors pressure management to settle faster and for more money. The nature of the D\&O insurance re-enforces this behavior. All of the named officers and directors of a firm share the same D\&O policy, so defense costs will exhaust the coverage faster when there are more defendants. This increases the risk that directors will pay out-of-pocket in a settlement. Since D\&O insurance covers only individuals and not the company, named directors have a say in how the insurance is used (Alexander, 1991).

At the same time, plaintiff attorneys tell us that they can incur costs if they name directors indiscriminately in lawsuits. They risk having their lawsuits dismissed as frivolous and can be sanctioned by courts for bringing frivolous claims. Such sanctions hurt their reputations and lower their chances of being certified as lead attorneys in class actions. Institutional investors, for their part, are likely to be cautious in hiring attorneys with bad reputations. Plaintiff attorneys also do not want to incur the costs of deposing numerous defendants. Multiple defendants exhaust D\&O insurance faster reducing the funds available for settlement and attorney fees. Finally, Black, Cheffins, and Klausner (2006a) suggest that trying a case with many individual defendants can confuse the jury jeopardizing the lawsuit. They thus posit that plaintiffs name independent directors initially for strategic reasons but eventually may remove their names. Also, our interviewees tell us that a director named in error will be removed from the complaint as

shareholder dissatisfaction. We identify when the lead plaintiff is an institutional investor to examine cases where large investors with potentially greater monitoring incentives are involved. 
the lawsuit proceeds. Since our named directors are from the final list of named parties, we expect there were reasons why these directors were named and stayed in the complaint compared with other independent directors.

\subsection{Accountability through Investor Voting in Director Elections}

Voting against a director's reelection is another means by which shareholders hold independent directors accountable. A few recent papers examine investor voting in response to director performance. Yermack (2010) contains a comprehensive review of the larger shareholder voting literature. Cai, Garner, and Walking (2009) find that directors receive fewer votes after a securities lawsuit and when the director serves on the board of another firm that faces a shareholder lawsuit. Where Cai, Garner, and Walking (2009) control for firm-level litigation and find that directors receive, on average, up to $1.29 \%$ less shareholder votes, we focus on a director-level analysis of shareholder votes and ISS recommendations in sued firms. Ertimur, Ferri, and Maber (2012) find that compensation committee members of option backdating firms receive fewer votes than other directors in these firms. Neither Cai, Garner, and Walking (2009) nor Ertimur, Ferri, and Maber (2012) examine whether shareholders target directors through litigation.

Several papers have highlighted the role of proxy advisory services, in particular ISS. They have found that ISS recommendations significantly influence proxy voting outcomes (Alexander, Chen, Seppi and Spatt, 2010; Cai, Garner, and Walking, 2009). Cai, Garner, and Walking (2009) find that an individual director's vote share drops by about $8 \%$ when ISS recommends shareholders vote against that director. Choi, Fisch, and Kahan (2009) provide evidence that ISS and other proxy advisors (Glass Lewis, Egan Jones, and Proxy Governance) recommendations are based on observable firm and 
director characteristics and that investor voting decisions are based on these observable characteristics and not on the recommendations per se.

The negative votes documented in Cai, Garner, and Walking (2009) and Fischer, Gramlich, Miller, and White (2009) are not economically large, but directors appear to heed to the votes. Cai, Garner, and Walking (2009) document a decrease in excess CEO compensation in the year following a higher negative vote for the compensation committee directors. They also find that the likelihood of CEO turnover increases when independent directors receive lower votes. Votes against directors also lead to director resignations. These findings resemble those in Fischer, Gramlich, Miller, and White (2009), who show that firms whose directors receive fewer votes are more likely to experience subsequent CEO turnover and to hire an outside CEO. These firms also experience greater board turnover, lower excess CEO compensation, and make better acquisition and spin-off decisions. Both Cai, Garner, and Walking (2009) and Fischer, Gramlich, Miller, and White (2009) conclude that their evidence suggests shareholder dissatisfaction expressed via withheld votes is associated with subsequent governance improvements in firms, which indicates that directors note the disapproval and respond.

Del Guerco, Seery, and Woidtke (2008) find that boards respond to "just vote no" campaigns where shareholders withhold votes for one or more directors' election. They report operating performance improvements and better CEO turnover performance sensitivity following such campaigns. Ertimur, Ferri, and Muslu (2011) show that excess CEO pay declines following “Vote No” campaigns. This evidence supports Grundfest’s (1993) conjecture that directors care about their reputations and even a symbolic negative vote is enough to shame a board to act. Collectively, evidence suggests that, even though 
the extent of negative voting against directors is modest and does not directly lead to director removal, votes withheld reflect shareholder displeasure and directors act as if they care about that displeasure.

\subsection{Accountability through director turnover}

Director turnover is another means for disciplining independent directors. Prior papers provide evidence that directors lose their seats when firms experience financial crises or financial misconduct (e.g., Gilson, 1990; Srinivasan, 2005; Ertimur, Ferri and Maber, 2012). In contrast, Agarwal, Jaffe, and Karpoff (1999) find that director turnover is unchanged after fraud, and Fich and Shivdasani (2007) find that directors do not leave a sued firm beyond normal levels: $83 \%$ of directors remain three years after the lawsuit. Agarwal, Jaffe, and Karpoff include other fraud in their sample, not just securities-related cases, hence their results are not directly comparable to the other papers. In Sec 5.3, we examine the Fich and Shivdasani results using our data and relate them to our results.

In related prior research, Romano (1991) examines firms subject to shareholder lawsuits from the late 1960s to 1987. She finds higher CEO and director turnover in sued firms compared with a matched sample, which she interprets as evidence of the disciplining effect of the lawsuits. Board turnover is higher when the suits are settled compared with the matched sample but does not differ between dismissed lawsuits and a matched sample. Also, board independence improves after a lawsuit. Farber (2005) corroborates this result by showing improved board independence in companies after SEC enforcement action which implies that directors are replaced. Ferris, Jagannathan, and Pritchard (2007) examine derivative lawsuits filed between 1982 and 1999 also finding an increase in board independence. They find that director turnover increases 
significantly in the three years after a lawsuit. Overall, the evidence points to higher board turnover after lawsuits, suggesting that directors are held accountable for monitoring failures. While prior papers consider the entire board as accountable for poor performance, we examine named directors to get more directly at the accountability question.

While we focus on accountability for directors, our paper is related to the literature on director reputation, which shows that directors incur labor market penalties when they are perceived as weak monitors (Srinivasan, 2005; Black, Cheffins, and Klausner, 2006a; Fich and Shivdasani, 2007). We examine loss of other directorships and voting in other boards in the additional analysis section. Prior evidence is consistent with ex post settling up in the market for directors (Fama, 1980; Fama and Jensen, 1983). But it could also reflect directors voluntarily leaving boards because of risk aversion following lawsuits or a desire to relieve themselves of the workload of serving troubled companies. Our voting analysis in other directorships is thus a better indication of the demand from investors for director performance.

\section{Sample Selection and Descriptive Evidence}

\subsection{Sample selection}

Our data on securities class-action litigation in the U.S. over the period 1996 through 2010 comes from the ISS Securities Class Action database. ${ }^{5}$ We match defendant

\footnotetext{
${ }^{5}$ The ISS database includes dates for class period start and end and for lawsuit filing, dismissal or settlement which we manually check for accuracy. Karpoff, Koester, Lee and Martin (2012) suggests that similar databases fail to capture initial fraud revelation dates correctly. Because ours is not an event study, our inferences are unlikely to be affected by this issue. However, measurement error in our control variables that rely on filing dates (stock price drop and trading volume) may weaken our tests. As a robustness check, we replace the class period stock price drop with two-year market-adjusted buy-and-hold returns measured prior to the first annual meeting following a lawsuit in our ISS recommendations,
} 
names from that database with names of independent directors from the IRRC database and names from SEC filings in the Thomson Insider Trading database. (We do this to measure shares sold by directors in the class period.) The intersection of IRRC with Compustat and CRSP, which we require for stock market and financial variables, results in 3,276 firms over the period. For this sample, we identify 921 lawsuits, which reduce to 805 lawsuits when we require firms to be in IRRC as of the lawsuit filing date. The 805 firms have 5,461 independent directors at the time the lawsuits are filed (affiliated or "gray" directors are not considered as independent). We create a matched sample of firms with similar ex-ante litigation risk as the sued firms following Rogers and Stocken (2005) (described in Appendix A). We match sued firms with non-sued firms by industry, year, size, performance, and estimated litigation risk. ${ }^{6}$ The matched sample has 805 non-sued firms with 4,739 independent directors.

\subsection{Descriptive statistics}

Table 1 reports descriptive statistics for our sample of sued firms and independent directors at the time of lawsuit filing. Panel A presents lawsuit characteristics for the entire sample (when the firm is available on Compustat and CRSP) and for the sample restricted to IRRC firms. Our subsequent tests are based on the IRRC sample. When compared with the full sample, the IRRC sample contains more lawsuits related to GAAP violations (57.55\% versus 46.50\%) but fewer Section 11 lawsuits (11.51\% versus 25.28\%). Since the Enron and WorldCom suits were Section 11 claims and since Sec. 11 makes it easier to sue directors, legal scholars have discussed the possibility of Sec. 11

shareholder voting and director turnover tests (not tabulated). Our conclusions remain unchanged by this change.

${ }^{6}$ More specifically, we rank firms by market capitalization and return on asset terciles within each industry-year, where industry is based on two-digit SIC code. Each sued firm is then matched to a non-sued firm with the highest estimated litigation risk among its peers (same industry, size tercile and ROA tercile). 
claims increasing against directors (Pritchard and Sale, 2005). ${ }^{7}$ We thus identify these lawsuits separately. Lead plaintiffs are more likely to be institutional investors (the rest being individuals) in the IRRC sample (53.09\% versus $37.12 \%$ ), probably because these firms are larger on average. Lawsuit settlement rate is lower in the IRRC sample (55.00\% versus 61.87\%), but settlements are larger (\$102 million versus \$43 million), though the relation reverses when measured as a percentage of assets (1.85\% versus $3.96 \%)$.

Panel B shows descriptive statistics for director characteristics in the IRRC and matched samples. Of the independent directors at lawsuit filing, $11 \%$ are named as defendants. Compared with independent directors of non-sued matched firm, independent directors in the sued firms are more likely to sell shares of their firms during the class period (11\% versus $9 \%$ ), and they sell more of their holdings (3.5 \% versus $0.19 \%$ ). There are also a smaller proportion of directors with tenure of one year or less in sued (17\%) compared with matched (20\%) firms. These differences are statistically significant at the mean and median levels. Means and medians are not significantly different between sample and matched observations for all other director characteristics. In both samples, about half of the independent directors are audit committee members.

Panel C reports descriptive statistics for firm characteristics in the IRRC lawsuit and matched samples. The mean (median) stock price drop as measured by the difference between the highest price during the class period and the price at the lawsuit filing date, scaled by the highest price, is $39 \%$ (44\%). None of the means and medians are significantly different between sample and matched observations in terms of firm size, performance, growth, industry and board size, except for class period price drop, which is

\footnotetext{
${ }^{7}$ Section 11 places a lower burden of proof on plaintiffs than 10b-5. PSLRA provisions relating to scienter, loss causation, and reliance that apply to $10 \mathrm{~b}-5$ claims do not apply to Section 11 claims (Pritchard and Sale, 2005). In terms of proof and pleading standards, Sec.11 is more plaintiff friendly than rule 10b-5.
} 
lower for matched firms than that for sued firms at the median level, and share turnover, which is significantly lower in the matched sample $(\mathrm{p}<0.01)$.

\section{Litigation Risk for Independent Directors}

\subsection{Determinants of directors being named as defendants in securities lawsuits}

We first examine the likelihood that a director is named as a defendant in securities class-action lawsuits.

\subsubsection{Univariate analysis}

Table 2 reports univariate comparison of director characteristics between independent directors that are named defendants (Column 1) and directors not named as defendants in sued firms (Column 2). The statistically significant differences are as follows. Named defendants are more likely to sell shares during the class period (16\% versus $11 \%$ ), and they sell a significantly larger portion of their holdings during the class

period (4.99\% versus 3.22\%) even though they hold similar amounts ( 0.14 versus 0.16 percent of outstanding equity). They are also more likely to serve on the audit committee (54\% versus $49 \%$ ) and have longer tenure when the lawsuit is filed (7.55 versus 6.68 years). They are more likely to have been on the board during the entire class period ( $86 \%$ versus $74 \%$ ) and less likely to be females (12\% versus $15 \%$ ). While we examine director-level litigation, the firm-level likelihood of having at least one independent director named as defendant in our sample is $17 \%$. The comparison of named and not named directors within firms with at least one named director leads to qualitatively similar inferences from the full sample (not tabulated.)

\subsubsection{Multivariate analysis}


We next examine whether the above differences hold in a multivariate setting by estimating the following logistic regression:

$$
\begin{gathered}
\operatorname{Pr}(\text { Named }=1)=\alpha_{0}+\sum_{i} \alpha_{i} \text { Director Characteristics } \\
+\sum_{j} \alpha_{j} \text { Lawsuit Characteristics }+\sum_{k} \alpha_{k} \text { Firm Characteristics }+\varepsilon
\end{gathered}
$$

where the dependent variable equals one if a director is a named defendant and zero otherwise. The sample consists of all independent directors on the board of a sued firm when the lawsuit is filed. We include three sets of independent variables: director-, lawsuit-, and firm-specific characteristics. Among director characteristics, we are interested in Audit Committee, which indicates whether a director is on the audit committee, and Shares Sold, which is the proportion of a director's stock holdings sold during the class period. We expect a positive coefficient on Audit Committee since material misstatements or lack of disclosure relate to oversight omissions on part of the audit committee. Sale of shares during the class period allows plaintiffs to allege fraudulent intent. \# Other Boards is the number of other directorships within the IRRC universe. If plaintiffs target "busy" directors as poor monitors (Ferris, Jagannathan, and Pritchard, 2003; Fich and Shivdasani, 2006), this variable will have a positive coefficient. We also include a director's age, gender and tenure at the firm, whether the director was on the board during the entire class period (On Board During Full Class Period), and their stock holdings scaled by shares outstanding (Shares Held). For lawsuit characteristics, we include an indicator variable for Section 11 lawsuits (Section 11), for which we expect more named directors, and for lawsuits which have related SEC action (SEC Action). We also control for lawsuits related to option backdating (Backdating). We include Institutional Lead Plaintiff (equal to one if the lead plaintiff is an institutional 
investor) because Cheng, Huang, Li, and Lobo (2010) report that the probability of surviving the motion to dismiss and settlement amount are higher when the lead plaintiff is an institutional investor. GAAP is equal to one if the lawsuit alleges GAAP (i.e., accounting) violation and zero otherwise. Log Class Period is the log of the number of days in the class period. Class Period Price Drop is the difference between the highest stock price during the class period and the price at the lawsuit filing date, scaled by the highest price. Share Turnover is the average daily share turnover during the class period measured by trading volume as a percentage of shares outstanding. (For NASDAQ stocks, we follow the methodology in Gao and Ritter, 2010.) We expect directors to be more likely to be blamed for more severe cases, i.e., those with a longer class period, a larger stock price decline, or both. Equity Issuance equals one if the firm issued common shares to the public during the class period and zero otherwise. Although Equity Issuance is correlated with Section 11 (the correlation being 0.20 ), we include it separately because equity issuance can be associated with earnings management (Teoh, Welch, and Wong, 1998). Other firm-level variables include market capitalization, return on assets, sales growth, an indicator for high litigation-risk industry, and board size. We add a variable Time measured as the year of the lawsuit filing, to capture any time varying effect in directors being named in lawsuits.

Table 3 reports results of the above estimation. The significantly positive marginal effect of Shares Sold and Audit Committee suggests that independent directors who sell more of their stock during the class period and audit committee members are more likely to be named as defendants. Directors who served on the board before the start 
of the class period (On Board During Full Class Period) are more likely to be named than those who joined after the beginning of the class period.

In terms of lawsuit characteristics, directors are more likely to be named in Section 11 (Section 11) and backdating (Backdating) lawsuits as well as when the lead plaintiff is an institutional investor (Institutional Lead Plaintiff). Surprisingly, the likelihood of being named decreases in the length of the class period (negative coefficient on Log Class Period) and in lawsuits that have related SEC Action, suggesting that directors are not necessarily named in the most severe cases. Later in the paper, we discuss whether naming directors is related to severity of the alleged wrongdoing or is a negotiating tactic by plaintiffs. Higher profitability $(R O A)$ lowers the likelihood that independent directors are named. Finally, the coefficient on Time is not significant, which indicates that the likelihood of directors being named in lawsuits has not increased over time, providing no support for concerns about increasing litigation risk for directors (Bebchuk, 2006).

\section{Shareholder Voting and Director Turnover in Litigation Firms}

We next examine shareholder voting and director turnover in the sued firms. For the voting tests, the sample consists of directors in the IRRC firms which are present in the ISS Voting Analytics database (available from 2001). The matched sample has directors from non-sued firms matched with the lawsuit sample as described earlier. Since we evaluate voting and turnover up to two years ahead, we exclude from these tests (i) lawsuits filed after 2008; (ii) firms that are not in IRRC in the two years following the lawsuit; and (iii) cases that have not reached a conclusion—dismissal or settlement. 


\subsection{Univariate evidence on shareholder voting and director turnover}

Table 4 presents univariate statistics on ISS recommendations, shareholder votes, and director turnover for non-named directors in sued companies (column 1), named directors (column 2), and matched sample directors (column 3). Both the ISS recommendation and shareholder votes are for the first election for the director after the lawsuit filing. In the case of staggered boards, we examine up to two elections after the lawsuit is filed. We measure director turnover when a person is no longer a director in the sued firm by the second annual meeting following the lawsuit filing date-the two-year window is used to be consistent with timing in the shareholder voting analysis. ISS "withhold" recommendations are significantly higher for not named sued firm directors (7.29\%) than for matched sample directors (5.78\%) and higher for named directors (23.88\%) than both not-named directors of sued firms and matched sample directors. As for shareholder voting, named directors receive significantly less support (10.50\% votes withheld) than not-named directors (6.13\%) and matched sample directors (5.03\%). Turnover for named directors is $22.36 \%$, which is significantly greater than $13.31 \%$ for non-named directors and $15.23 \%$ for matched directors.

These results are consistent with named directors being held accountable in sued firms for their role in securities law violation.

\subsection{Multivariate analysis of ISS recommendations and director elections in sued firms}

We extend the above univariate voting results with two sets of multivariate tests. First, we run a logistic regression where the dependent variable is ISS Withhold, an indicator variable equal to one if ISS issues a "withhold" or "against" recommendation for a director's election and zero otherwise. The independent variables are the same as in 
Model (2), except that we add an indicator variable for new directors (New Director), defined as directors with tenure of one year or less following Ertimur, Ferri and Maber (2012), because those directors are less likely to be blamed for the alleged wrongdoing. A positive coefficient on Named in Lawsuit would suggest that ISS takes into account named directors when issuing unfavorable recommendations or that ISS's policies target directors that are more likely to be named, such as those on the audit committee.

Second, we run an OLS regression where the dependent variable is shareholder votes withheld as a percentage of votes cast for a director in the first election for the director held within two years of the lawsuit filing. ${ }^{8}$ The main variable of interest is Named in Lawsuit, the coefficient on which should be positive if shareholders express greater dissatisfaction with a named director.

Table 5 reports the results for the above analysis. In Panel A, we first report logistic regression marginal effects for the ISS recommendation analysis. The significantly positive effect on Named in Lawsuit (marginal effect $=6.40$, p-value $<0.05$ ) indicates that ISS is more likely to recommend "withhold" for named directors. ISS also recommends voting against directors in Section 11 lawsuit companies, where the stock price decline and trading volumes were greater during the class period, for larger firms, and firms in high litigation risk industries. Surprisingly, the coefficient on Settled is negative, implying that ISS recommends "withhold" less in settled cases than in dismissed ones. ${ }^{9}$

\footnotetext{
${ }^{8}$ In untabulated tests, we find similar results when we include votes as far as three years ahead. Note that the named directors at the time of the initial vote may not be exactly the final list of named directors that we measure because some directors may be named at the beginning but subsequently removed.

${ }^{9}$ To understand this puzzling result, we examined ISS recommendations for cases that are dismissed quickly (within a year) versus those that are dismissed slowly (more than a year) under the assumption that in quickly dismissed cases, shareholders and ISS would find out sooner about the outcome and be more lenient and slowly dismissed cases would exhibit outcomes closer to that for settled cases. We find that ISS
} 
The third and fourth columns report regression coefficients and $t$-statistics where the dependent variable is votes withheld as a percentage of votes cast. The positive and significant coefficient on Named in Lawsuit indicates that named directors receive, on average, $4.24 \%$ less shareholder support, controlling for other factors. Shareholder support for directors is significantly lower in lawsuits (i) filed under Section 11, (ii) alleging GAAP violations, (iii) for those where a company's stock is more actively traded during the class period, (v) for larger firms, (vi) those in high litigation risk industries, and (vii) those with smaller boards. Shareholders seem to discriminate between new and existing directors, with higher support for the directors who joined the board recently. ${ }^{10}$

In Panel B, we distinguish between named directors in cases that are dismissed versus those that are settled. For interaction terms in logistic regressions, we report mean marginal effects and significance levels following Ai and Norton (2003). We also report F-tests for coefficient sums, which enable us to examine the effect of being a named director in each sample partition. For example, F (Named \& Settled) indicates whether the sum of the coefficients on Named in Lawsuit and Named in Lawsuit $\times$ Settled equals zero, and measures the overall effect of being named as a defendant on the likelihood of receiving an unfavorable recommendation from ISS in settled cases. ${ }^{11}$ The coefficient on

recommendations for not-named directors are more negative for both quickly and slowly dismissed cases compared with settled ones. One possibility is that ISS encourages shareholders who fail in court to vote negatively to voice their displeasure with directors in the sued firm. We do not, however, have direct evidence of this conjecture. We also did not find that quickly dismissed cases name more independent directors than slowly dismissed ones or cases that are settled.

${ }^{10}$ Our voting regression excludes the strongest predictor of shareholder voting - ISS's recommendation. We omit it to identify primitive factors that drive voting following Choi, Fisch, and Kahan (2009). When we include a variable for an unfavorable ISS recommendation, the model $\mathrm{R}^{2}$ increase from 20 to $52 \%$, consistent with recommendations being influential.

${ }^{11}$ The sum of the coefficients on Named in Lawsuit and Named in Lawsuit $\times$ Settled provides the overall effect of being named in the partition of interest i.e., settled cases. We repeat similar tests in subsequent tables where we assess the effect of being a named director on different partitions of interest - settled cases, audit committee directors and the post-2002 time period. The F-tests allow us to assess if the outcome being examined is significant for named directors within the partition of interest. 
Named in Lawsuit measures that effect for dismissed cases only, while the coefficient on Named in Lawsuit $\times$ Settled measures the incremental effect of settled versus dismissed cases. Following Greene (2010), F-tests are based on model coefficients.

In terms of impact on named directors, there is no significant difference between dismissed and settled cases, based on the insignificant marginal effect and coefficient on Named in Lawsuit $\times$ Settled, which is puzzling if dismissed cases have less merit. ${ }^{12}$ Nevertheless, the significantly positive coefficients on Named in Lawsuit and the F-tests ( $F=4.58$ for ISS recommendations; $F=2.75$ for shareholder votes) suggest that named directors are less likely to receive support from ISS and from shareholders compared with not-named directors in both dismissed and settled cases, respectively.

In Panel C, we separately analyze named directors who are audit committee members and others, because compliance with securities laws likely falls under the purview of the audit committee. The insignificant interaction effects Named in Lawsuit $\times$ Audit Committee indicate that audit committee members who are named defendants receive no less support from shareholders or ISS than other named independent directors. The F-tests suggest that named audit committee members receive significantly lower support than not-named directors ( $\mathrm{F}=7.61$ for ISS recommendations; $\mathrm{F}=3.87$ for shareholder votes). For non-audit committee members, the effect of being named is seen only in shareholder votes (coefficient $=4.71 \%, \mathrm{p}<0.05$ ) and not ISS recommendations.

\footnotetext{
${ }^{12}$ Directors will face lower penalty in dismissed cases if these cases have lesser merit than settled ones. Johnson, Nelson, and Pritchard (2009) find that accounting errors are the main merit-related factor in dismissal prediction. Prediction models have only a modest ability to predict dismissals. The noisy nature of the dismissal variable as a proxy for merit likely drives the lack of difference in this test. The other possibility we examine later is that plaintiffs name directors strategically and not just in relation to case severity.
} 
Next we investigate ISS recommendations and shareholder voting for sued directors compared with matched directors. We separate directors of sued firms into those that are not named in the lawsuit (Not Named in Lawsuit) and the named defendants (Named in Lawsuit). We exclude lawsuit characteristics as explanatory variables in this test. Table 6 presents results of this estimation. ${ }^{13}$

In Panel A, the positive marginal effects on Named in Lawsuit and Not Named in Lawsuit indicate that ISS is more likely to recommend voting against both named and not-named directors of sued firms. The effect of Named in Lawsuit is significantly greater than the one of Not Named in Lawsuit (F-test p-value <0.01). In the voting regression results, the coefficients on Not Named in Lawsuit and Named in Lawsuit are both significantly positive, which indicates that directors from lawsuit firms receive lower shareholder support in their elections compared with matched directors - $1.10 \%$ for nonnamed directors and $5.27 \%$ for named directors, respectively. Furthermore, the coefficient on Named in Lawsuit is significantly greater than the one on Not Named in Lawsuit, showing that named directors receive fewer votes than non-named directors (Ftest $\mathrm{p}$ value $<0.01) .^{14}$

In Panel B, we partition the sample by dismissed versus settled cases. The insignificant coefficient on the interaction terms Named in Lawsuit $\times$ Settled in both ISS and shareholder voting indicates that there is no different effect between dismissed and

\footnotetext{
${ }^{13}$ We create separate variables for sub-groups of directors because named directors are a subset of sued firm directors. That is, Named in Lawsuit and Not Named in Lawsuit are mutually exclusive. This also eliminates double interaction terms in subsample analyses and related inference issues (Ai and Norton, 2003).

${ }^{14}$ We cannot measure ISS recommendation or shareholder votes for $13 \%$ of directors because they leave the board before re-election. We use a Heckman procedure to model the likelihood that a director will leave before re-election (using director age and staggered board as instruments) in a first stage and the inverse Mills ratio in the second stage analysis of ISS recommendation and shareholder votes. We find no evidence that the coefficients of interest differ significantly with those from the one-stage model (not tabulated).
} 
settled cases for named defendants. The F-tests show that named directors do worse with both ISS and shareholders than not-named directors in both dismissed ( $F=9.68$ for ISS recommendations and $\mathrm{F}=4.73$ for shareholder votes) and settled cases ( $\mathrm{F}=8.75$ for ISS recommendations and $\mathrm{F}=3.31$ for shareholder votes.)

In Panel C, we partition between audit committee members and others. The insignificant coefficient on the interaction terms Named in Lawsuit $\times$ Audit Committee in both ISS and shareholder voting indicates that there is no incremental effect of being an audit committee member over being named defendant. The F-tests show that named directors do worse with both ISS and shareholders than not-named directors whether they are audit committee members ( $\mathrm{F}=16.05$ for ISS recommendations and $\mathrm{F}=5.15$ for shareholder votes) or not $(\mathrm{F}=2.74$ for ISS recommendations and $\mathrm{F}=5.62$ for shareholder votes.)

\subsection{Director turnover in sued firms}

Next we examine the likelihood of a named independent director continuing on the board relative to other independent directors. We include all director, lawsuit, and firm characteristics from Model (2) to control for factors potentially correlated with director turnover and the likelihood of being named a defendant. We repeat the analysis after including directors of matched non-sued firms.

Table 7 Panel A presents the results. In the first two columns, we present the logistic regression marginal effects and z-statistics where the dependent variable is director turnover and the sample consists of directors of sued firms. The significantly positive marginal effect of Named in Lawsuit indicates that named directors are more likely to lose their seat within two years, consistent with the univariate results in Table 4. 
Director turnover is also higher for directors who are 65 years old and older. In terms of lawsuit characteristics, Section 11 lawsuits and class period length exhibit a significantly positive association with director turnover. Firms in high litigation risk industries show lower board turnover.

In the next two columns with matched firm directors, the marginal effect of Named in Lawsuit is significantly positive $(\mathrm{p}<0.10)$ and greater than the one on Not Named in Lawsuit (F-test: $\mathrm{p}<0.01$ ). However, Not Named in Lawsuit itself is negative and significant, indicating lower turnover among non-named directors in sued firms than those in matched firms. Audit Committee also exhibits lower turnover after controlling for named directors. These results suggest that companies undergoing crises retain directors who are not implicated in the wrongdoing, perhaps to maintain continuity.

In Panel B, we include interaction effects for settled cases. For the lawsuit sample, the main effect of being named (implicitly dismissed cases) is not significant. However, the incremental effect (Named in Lawsuit $\times$ Settled) is significantly positive, implying that among named defendants, those in settled cases are more likely to leave than in dismissed cases. Moreover, the sum of Named in Lawsuit and Named in Lawsuit $\times$ Settled is also significantly positive ( $\mathrm{F}=9.86)$. We observe similar results including the matched sample. F-tests indicate that in settled cases, named defendants are significantly more likely to lose their seats than non-named directors $(\mathrm{F}=15.79)$, but not in dismissed ones $(\mathrm{F}=0.80)$. Overall, this implies that the effect of turnover on named directors arises from settled cases.

In Panel C, we look separately at audit committee members and other independent directors. Within the lawsuit sample, the main effect of being named (implicitly for non- 
audit committee members) is not significant. Named audit committee members are significantly more likely to leave (F-test: Named \& Audit Committee) than all other directors of sued firms (F=7.35). However, the incremental effect of Named in Lawsuit $\times$ Audit Committee is not statistically significant. The matched sample results are similar. Named audit committee members are significantly more likely to leave (F-test: Named \& Audit Committee) than matched directors ( $\mathrm{F}=7.25)$, and among audit committee members of sued firms, named directors are significantly more likely than others to lose their seats $(\mathrm{F}=8.87)$.

In Panel D, we look separately at cases filed before and after 2002. We use post2002 to identify a period of greater accountability for boards following the corporate scandals of early 2000s and enactment of SOX. We report three findings. First, director turnover in sued firms increased post-2002 (significant marginal effect of Post-2002 in the first regression) but not in matched firms, reflecting greater sensitivity towards directors' role in corporate failures. Second, the effect comes from both named and notnamed directors, based on the two significantly positive interaction terms in the second regression. Third, post-2002, named directors are more likely to leave than not-named ones $(\mathrm{F}=9.41)$. Surprisingly, the main effect on Not Named in Lawsuit is negative and significant. This implies that, pre-2002, not named directors of sued firms were less likely to leave than directors of matched firms. This could be because the sued firms wish to retain non-tainted directors to maintain continuity, given the turnover of named directors.

These results relate to those in Fich and Shivdasani (2007). Their work finds a $17 \%$ board turnover rate in the three years following a lawsuit using a sample of lawsuits between 1998 and 2002 (they provide univariate analysis only), which they conclude is 
not abnormal. In untabulated results, we replicate our tests relating to named defendants after restricting our sample to the 1998-2002 period, and find no greater board turnover in the three years following the lawsuit compared with the matched sample. However, we find that named directors in that period are subject to greater turnover than other directors of sued firms. Thus our results indicate that the likelihood of director turnover has increased after 2002 and is now a significant effect. Moreover, named directors appear to be the ones more affected in the post-2002 period.

\section{Shareholder Voting and Director Turnover in Other Firms}

We extend our voting and director turnover results to other directorships of sued firm directors. While our focus is on director accountability in sued firms, we examine the reputational impact of named directors to inform the literature on reputational penalties for independent directors. Fama (1980) and Fama and Jensen (1983) posit that firm performance affects directors' reputations as corporate stewards, which are rewarded or penalized in the market for directorships. Prior papers have found evidence that directors lose their positions on other boards when they serve as directors of firms experiencing a financial crisis or financial misconduct (e.g., Srinivasan, 2005; Fich and Shivdasani, 2007; Ertimur, Ferri and Maber, 2012). Fich and Shivdasani find a reduction in other directorships for sued-firm directors, which they attribute to loss of reputation. While this evidence is consistent with ex post settling up in the market for directors reflecting a reputational cost, the evidence could also reflect directors voluntarily stepping down from board positions due to increased risk aversion. Fich and Shivdasani explore alternate explanations and find most support for the reputation 
hypothesis. They also find that directors are more likely to lose directorships in firms with high risk of being sued for fraud, suggesting a risk-reduction motive for directors.

To examine reputational penalties in our sample, we test whether directors of sued firms are more likely to (a) receive an ISS withhold recommendation in another directorship, (b) receive lower shareholder support in their elections in other firms compared with independent directors from firms matched on litigation risk who hold board seats outside of the matched firms, and (c) lose board seats in other firms. We also conduct within lawsuit-sample analysis to compare named and non-named directors.

Table 8 reports the results. We find no significant relation between Named in Lawsuit (or Not Named in Lawsuit) and ISS recommendations or shareholder votes in other directorships. However, we do find a loss in other board positions for both named defendants (significant coefficient on Named in Lawsuit) and other directors of sued firms (Not Named in Lawsuit). There is no difference in coefficients between Named in Lawsuit and Not Named in Lawsuit implying the other directorships loss is no different between named or other directors. In untabulated tests, we find limited evidence of a statistically significant increase in director turnover in other board seats after 2002 ( $\mathrm{p}=0.05$ for all directors of sued firms, and $\mathrm{p}=0.11$ for named and not-named directors separately.) These findings suggest that reputational penalties reflected in losses of other board positions are not mirrored in shareholder votes in other directorships, and that investors are not the means by which reputational costs are transmitted.

\section{Lawsuit Outcomes When Independent Directors are Defendants}


We next examine whether lawsuit outcomes vary depending on whether independent directors are named as defendants. Our aim is to understand the economic implications of involving these directors in a lawsuit. We use the following model:

Outcome $=f(\#$ Named, Lawsuit Characteristics, Firm Characteristics $)$

where Outcome is one the following three variables: Dismissal, an indicator equal to one if the case is dismissed and zero otherwise; Time to Settlement, which is the number of days between the filing date and the settlement date; Settlement Amount, which is the log of the total dollar value of the lawsuit settlement.

The relation between lawsuit outcomes and number of independent directors named can be driven by two factors. First, plaintiffs can name more independent directors in more serious cases, which have lower chances of dismissal and bigger potential settlements. A longer-duration fraud or a highly egregious one might indicate that more directors were negligent. In this case, the number of directors named is a proxy for lawsuit severity. Plaintiffs, for example, named 14 directors in Enron and 10 in WorldCom — two of the largest groups of named director defendants, likely reflecting the severity of the cases. On the other hand, severity and named directors could be unrelated since fraud could involve deception by managers, and independent directors might be unaware. Secondly, naming independent directors can also be a negotiating tactic by plaintiffs and their attorneys, as discussed in Section 2.1. We first examine whether the number of named independent directors affects lawsuit outcomes and then whether the outcomes can be attributed to negotiating pressure.

With Dismissal as the dependent variable, we use a logistic specification. The variable of interest \# Directors Named equals the number of independent directors named 
as defendants. With Time to Settlement as the dependent variable, we use a Cox proportional hazard model. Quicker settlement is presumably in the interest of both plaintiffs and defendants. If cases with named directors settle faster, the coefficient on \# Directors Named should be positive. With Settlement Amount as the dependent variable, we use an OLS regression with only settled cases as the sample. We expect a positive coefficient on \# Directors Named, i.e., cases with more named directors result in larger settlements. The other independent variables are the same lawsuit and firm-level variables as in Model (2).

Table 9 presents the results. In all three tests, we include fixed effects for year and the federal court where the suit is filed. The first set of two columns reports marginal effects and z-statistics for lawsuit dismissal analysis. The significantly negative marginal effect on \# Directors Named $(\mathrm{p}<0.01)$ indicates that, the more independent directors are named in a lawsuit, the less likely the lawsuit is to be dismissed. The likelihood of dismissal is also lower for (i) Section 11 cases and for suits where (ii) plaintiffs allege GAAP violations, (iii) the lead plaintiff is an institutional investor, and (iv) the class period is longer. Larger firms are more successful in getting suits dismissed $(\mathrm{p}<0.05)$.

The second set of columns reports results from the analysis of settlement speed. We find a positive coefficient on \# Directors Named $(\mathrm{p}<0.10)$, indicating that settlement speed increases with the number of named directors. Cases (i) with allegations of GAAP violations and (ii) where the SEC pursues enforcement action are associated with shorter settlement times, while cases with an institutional lead plaintiff are slower to settle.

The third set of columns presents OLS coefficients and t-statistics, where the dependent variable is the log dollar amount of the settlement (Cheng, Huang, Li, and 
Lobo 2010). ${ }^{15}$ The coefficient on \# Directors Named is significantly positive $(\mathrm{p}<0.01)$, which indicates that, the more independent directors are named, the larger the settlement amount. The results also indicate that lawsuits that (i) allege GAAP violations, (ii) are filed under Section 11, (iii) involve an SEC action, (iv) have an institutional investor lead plaintiff, (v) are filed against larger firms, (vi) have longer class periods, and (vii) have higher share turnover during the class period have higher settlement amounts at statistically significant levels.

Overall, Table 9 indicates that directors are named as defendants in cases that are less likely to be dismissed, settle faster, and settle for a larger amount.

Note that, in all the tests in Table 9, we control for various proxies of lawsuit severity. To the extent our proxies capture all dimensions of severity, the significant coefficients on \# Directors Named indicate an effect incremental to lawsuit severity. However, since there likely are omitted correlated variables in the model and unobservable dimensions to lawsuit severity the coefficient on \# Directors Named can pick up some effects of lawsuit severity. We examine the possibility that plaintiffs name directors to gain negotiating advantage by identifying plaintiff types that are most likely to be strategic and interested in pursuing stringent case outcomes. ${ }^{16}$ Among plaintiff investors, we identify public and union pension funds (Public Lead Plaintiffs) such as CALPERS, the AFL-CIO, and the New York State Retirement Fund as among the most interested in holding directors accountable. CALPERS was the lead plaintiff in the Enron

\footnotetext{
${ }^{15}$ The inferences relating to \# Directors Named from this test are robust to using settlements scaled by assets as the dependent variable.

${ }^{16}$ Recall also Table 3 results that there was no positive relation between likelihood of being a named directors and either class period price drop, cases that were followed by SEC investigations, those with longer class periods. These results also suggest that there is no obvious relation between naming directors and severity of the case and that strategic considerations are important in naming defendants.
} 
case, and New York State Treasurer in the WorldCom case. Among attorneys, we identify plaintiff law firms that are in the top quartile of all law firms in terms of lawsuits filed-these being the most active securities class-action lawyers (High Profile Lawyers) who would have a stake in maintaining reputations as tough negotiators. We repeat the Table 9 analysis by adding these two variables by themselves and as an interaction with \# Named Directors. We find a significant main effect of Public Lead Plaintiff in all three outcomes: fewer dismissals, slower time to settlement, and higher settlement amounts. The interactions of \# Directors Named and both High Profile Lawyers and Public Lead Plaintiff exhibit a positive and significant coefficient in the settlement amount tests.

Overall, these supplemental tests suggest that plaintiffs with greater negotiating power strategically name directors as defendants in lawsuits. Note, however, that we are observing an endogenous process where plaintiffs likely consider the severity of a case in their decision to pursue it. Hence our results merely suggest that independent directors are, in equilibrium, named in lawsuits that result in larger settlements. We are also limited in our analysis since we do not observe the extent of D\&O insurance, which is likely to influence the extent and timing of settlement.

\section{Additional Analysis}

\subsection{Role of firm governance}

We examine whether overall firm governance figures in the effects documented throughout the main analysis. We use the G-index from Gompers, Ishii, and Metrick (2003) to proxy for firm-level governance quality, measured prior to the lawsuit. In untabulated results, we find that named directors receive less favorable recommendations from ISS, lower shareholder support for their elections, and are more likely to lose board 
seats in sued firms with higher G-Index, i.e., weaker governance. The above results indicate that firm governance has a significant effect on the relations we document. Shareholders hold independent directors of poorly governed firms more accountable when they are named in securities lawsuits. ${ }^{17}$

\subsection{Benchmarking stock sales by directors}

Prior research suggests that some independent directors time their stock sales profitably ahead of bad news earnings and earning restatements (Ravina and Sapienza, 2010). But many stock sales are likely to be driven by liquidity and portfolio rebalancing needs, not intent to defraud investors. While stock sales can be perceived as evidence of wrongdoing (Johnson, Nelson, and Pritchard, 2009), courts are more discriminating when assessing whether they constitute evidence of scienter (Sale, 2002; Pritchard and Sale, 2005). To examine whether independent directors are more likely to be named when selling abnormal amounts of stock, we employ several techniques to tease out routine from non-routine sales. In particular, we compare sales made by directors of sued firms during the class period with (i) their own sales during a period of equal length before the class period, (ii) sales made by independent directors of matched firms during the class period, (iii) sales made pursuant to Rule 10b5-1, which provides a safe harbor against allegations of trading on the basis of material nonpublic information, and separating (iv) routine from non-routine sales following the model in Cohen, Malloy and Pomoroski (2012). Untabulated results indicate that the likelihood of directors being named as defendants does not differ significantly depending on whether stock sales are classified as

\footnotetext{
${ }^{17}$ Further, settlements are significantly more likely to include provisions requiring firms to improve their governance when independent directors are named as defendants. While the association is statistically significant, it is limited to 15 cases in our sample, so the economic significance is limited (not tabulated).
} 
"normal" according to any of the aforementioned tests. We do, however, find a significantly negative coefficient on the interaction between stock sales and director tenure when predicting director naming, suggesting that directors who accumulate more stock because of seniority are less likely to be named for a given amount of stock sold. Overall, though, it appears as if directors are at greater risk of being named defendants if they sell shares regardless of how normal their trading activity is, which also supports the interpretation of the defendant naming process as being part of a negotiation tactic.

We replace Shares Sold in all the prior tables with abnormal shares sold using the pre-class period benchmark and find no difference in the reported inferences.

\section{Conclusion}

We examine which independent directors shareholders hold accountable for corporate financial fraud by looking at the incidence of directors being named as defendants in shareholder litigation, shareholder voting, and director turnover. We use a sample of firms that were sued for Securities Act violations under Section 10b-5 or Section 11 claims between 1996 and 2010.

We find that $11 \%$ of independent directors are named as defendants in securities lawsuits when the company they serve is sued. We further find that audit committee directors (consistent with concerns about litigation exposure of these directors) and those that sell shares during the class period are more likely to be sued.

Besides accountability through litigation, shareholders in sued firms also hold independent directors accountable by voting against them, including a greater negative 
vote for named directors. Proxy advisor ISS recommends a greater negative vote against directors in sued firms, especially those who are named in the lawsuit.

Directors of sued firms, and especially those who are named, are also significantly more likely to lose their board seats in the sued firm. This effect is more pronounced after 2002 than before, possibly reflecting greater sensitivity towards the role of corporate directors in recent corporate scandals. While Fich and Shivdasani (2007) show that lawsuits affect seats on external boards but not own-board turnover, our empirical findings suggest that at least part of this puzzle relates to whether a director is named in the lawsuit or not.

Finally, our results suggest that lawsuit outcomes vary when independent directors are named in lawsuits. When directors are named, cases are less likely to be dismissed, and they settle faster and for greater amounts. Some of our evidence points to the strategic naming of independent directors by the plaintiffs to gain bigger settlements.

Overall, our results provide an empirical estimate of the extent of accountability that independent directors' bear for corporate problems that lead to securities class-action litigation. These results are useful for independent directors to assess the extent of risk they face from litigation, shareholder voting, and departure from boards of sued firms. While the percentage of named directors is small compared with the overall population of directors, individual directors can weigh their risk differently. From a policy perspective, our results provide insight on the role investors' play in holding directors accountable for corporate performance. 


\section{Appendix A: Litigation Risk Estimation}

Similar to Rogers and Stocken (2005), we run the following logistic model to estimate firm-year specific litigation risk:

$$
\begin{aligned}
\operatorname{Pr}\left(\text { Lawsuit }_{i t}=1\right)= & f\left(\alpha_{0, t}+\alpha_{1, t} \text { Size }_{i t}+\alpha_{2, t} \text { Turn }_{i t}+\alpha_{3, t} \text { Beta }_{i t}+\alpha_{4, t} \text { Returns }_{i t}\right. \\
& +\alpha_{5, t} \text { Std }_{-} \text {Ret }_{i t}+\alpha_{6, t} \text { Skewness }_{i t}+\alpha_{7, t} \text { Min_Ret }_{i t} \\
& \left.+\sum \text { High Risk Industries }+\sum \text { Years }+\varepsilon_{t}\right)
\end{aligned}
$$

Where the dependent variable is equal to one if a securities lawsuit is filed against firm $i$ during year $t$ and zero otherwise. We estimate the coefficients over the 1996-2010 period, using firms with data available on CRSP. Securities lawsuits are obtained from the ISS Securities Class Action database. We eliminate cases related to IPOs and sell-side analysts. Size is the natural log of the average market capitalization. Turn is the average daily trading volume divided by the average shares outstanding. Beta is the slope coefficient from a regression of daily returns on the CRSP Equal-Weighted Index. Returns is the cumulative buy-and-hold return. Std_Ret is the standard deviation of daily returns. Skewness is the skewness of daily returns. Min_Ret is the minimum daily return. The high-risk industry variable indicate biotechnology (SIC 2833-2836), computer hardware (SIC 3570-3577), electronics (SIC 3600-3674), retailing (SIC 5200-5961) and computer software (SIC 7371-7379). We report coefficients and standard errors for the model below:

\begin{tabular}{lrc}
\hline \multicolumn{1}{c}{ Variable } & Coefficient & $\begin{array}{c}\text { Standard } \\
\text { Error }\end{array}$ \\
\hline Intercept & $-10.90^{* * *}$ & 0.17 \\
Size & $0.44^{* * *}$ & 0.01 \\
Turn & $0.43^{* * *}$ & 0.17 \\
Beta & $0.03 * * *$ & 0.01 \\
Returns & $-0.43 * * *$ & 0.03 \\
Std_Ret & $2.82 * * *$ & 0.89 \\
Skewness & -0.02 & 0.01 \\
Min_Ret & $-6.96 * * *$ & 0.21 \\
Biotechnology & 0.12 & 0.11 \\
Computer Hardware & $0.38 * * *$ & 0.13 \\
Electronics & $0.25 * * *$ & 0.08 \\
Retailing & 0.01 & 0.10 \\
Computer Software & $0.29 * * *$ & 0.08 \\
\hline Pseudo R ${ }^{2}$ N (Total) & \multicolumn{2}{c}{$18.93 \%$} \\
\multicolumn{2}{c}{113,827} \\
\hline
\end{tabular}




\section{References}

Agarwal, A., Jaffe, J. F., Karpoff, J. M. "Management turnover and governance changes following the revelation of fraud.” Journal of Law and Economics 17 (1999): 309-42.

Ai, C., Norton, E. C. 2003. "Interaction Terms in Logit and Probit Models." Economics Letters 80 (1): 123-9.

Alexander, J. C., 1991. Do the merits matter? A study of settlements in securities class action. The Stanford Law Review 43, 497-598.

Alexander, C., Chen, M., Seppi, D., Spatt., C. 2010. Interim news and the role of proxy voting advice. The Review of Financial Studies 23, 4419-4454.

Armour, J., Black, B., Cheffins, B., Nolan, R., 2009. Private enforcement of corporate law: An empirical comparison of the United Kingdom and the United States. Journal of Empirical Legal Studies 6, 687-722.

Bebchuk, L. A., 2005. The case for increasing shareholder power. Harvard Law Review 118, 833-914.

Bebchuk, L. A., 2006. Symposium on director liability. Delaware Journal of Corporate Law 31, 1011-1045.

Bebchuk, L. A., 2007. The myth of the shareholder franchise. Virginia Law Review 93, 675-732.

Black, B., Cheffins, B., Klausner, M., 2006a. Outside director liability. Stanford Law Review 58, 1055-1160.

Black, B., Cheffins, B., Klausner, M., 2006b. Outside director liability: A policy analysis. Journal of Institutional and Theoretical Economics 162, 5-20.

Cai, J., Garner, J., Walkling, R., 2009. Electing directors. Journal of Finance 64, 23892421.

Cheng A., Huang, H., Li, Y., Lobo, G., 2010. Institutional monitoring through shareholder litigation. Journal of Financial Economics 95, 356-383.

Choi, S., Fisch, J., Kahan, M., 2009. Director elections and the role of proxy advisors. Southern California Law Review 82, 649-702.

Cohen, L., Malloy, C., Pomorski, L., 2012. Decoding inside information. Journal of Finance 67, 1009-1043. 
Committee on Capital Markets Regulation, 2006. "Interim report of the committee on capital markets regulation” available at http://capmktsreg.org/2006/11/interim-report/.

Del Guercio, D., Seery, L., Woidtke, T., 2008. Do boards pay attention when institutional investors “just vote no”? Journal of Financial Economics 90, 84-103.

Ertimur, Y., Ferri, F., Maber, D., 2012. Reputation penalties for poor monitoring of executive pay: Evidence from option backdating. Journal of Financial Economics 104, 118-144.

Ertimur, Y., Ferri, F., Muslu, V., 2011. Shareholder activism and CEO pay. Review of Financial Studies 24, 535-592.

Fama, E., 1980. Agency problems and the theory of the firm. Journal of Political Economy 88, 288-307.

Fama, E., Jensen, M., 1983. Separation of ownership and control. Journal of Law and Economics 26, 301-25.

Farber, D., 2005. Restoring trust after fraud: Does corporate governance matter? The Accounting Review 80, 539-561

Ferris, S., Jagannathan, M., Pritchard, A., 2003. Too busy to mind the business? Monitoring by directors with multiple board appointments. Journal of Finance 58, 1087-1112.

Fich, E., Shivdasani, A., 2006. Are busy boards effective monitors? Journal of Finance 61, 689-724.

Fich, E., Shivdasani, A., 2007. Financial fraud, director reputation, and shareholder wealth. Journal of Financial Economics 86, 306-336.

Fischer, P., Gramlich, J., Miller, B., White, H. 2009. Investor perceptions of board performance: Evidence from uncontested director elections. Journal of Accounting and Economics 48, 172-189.

Gao, X., Ritter, J. 2010. The marketing of seasoned equity offerings. Working paper, University of Hong Kong and University of Florida.

Gilson, S.C. "Bankruptcy, boards, banks, and bondholders: Evidence on changes in corporate ownership and control when firms default.” Journal of Financial Economics 27 (1990): 355-88.

Gompers, P., Ishii, J., Metrick, A. 2003, “Corporate governance and equity prices,” Quarterly Journal of Economics, 118, 107-155. 
Greene, W. H. 2010. “Testing Hypotheses about Interaction Terms in non-Linear Models.” Economic Letters 107 (2): 291-6.

Grundfest, J.A. 1993. Just vote no: a minimalist strategy for dealing with barbarians inside the gates. Stanford Law Review 45: 857-937.

Hartzell, J. C., Starks, L. T. (2003), Institutional investors and executive compensation. The Journal of Finance, 58: 2351-2374.

Johnson, M. F., Nelson, K. K., Pritchard, A. C. 2007. "Do the merits matter more? The impact of the Private Securities Litigation Reform Act,” 23 J. of Law, Economics \& Organization 627.

Karpoff, J., Koester, A., Lee, D., Martin, G. 2012. An analysis of database challenges in financial misconduct research. Working paper, University of Washington.

Laux, V 2010. Effects of litigation risk on board oversight and CEO incentive pay. Management Science 56 (6): 938-948.

Office of the New York State Comptroller, 2005. Press Release "Hevesi announces historic settlement, former WorldCom directors to pay from own pockets” (Jan. 7, 2005) available at http://www.osc.state.ny.us/press/releases/jan05/010705.htm.

Pritchard A. C., Hillary, A. S. 2005. "What counts as fraud? An empirical study of motions to dismiss under the Private Securities Litigation Reform Act." Journal of Empirical Legal Studies. 2, no. 1 (2005): 125-49.

Ravina, E., Sapienza, P. 2010. What do independent directors know? Evidence from their trading. Review of Financial Studies 23 (3): 962-1003.

Rogers, J., Stocken, P. 2005. Credibility of management forecasts. The Accounting Review 80 (4): 1233-1260.

Romano, R. 1989. What went wrong with directors' and officers' liability insurance? 14 Delaware Journal of Corporate Law 1: 1-2.

Romano, R. 1991. The shareholder suit: litigation without foundation?, Journal of Law, Economics, and Organization, 7 (1): 55-87

Sahlman, W. 1990. Why sane people shouldn't serve on public boards. Harvard Business Review 68 (3): Art. 90312.

Sale, H. A. 2006. Independent directors as securities monitors. Business Lawyer 61: 1375-1413. 
Securities and Exchange Commission, 2009, Proxy disclosure enhancements - Release Nos. 33-9089; 34-61175 available at http://www.sec.gov/rules/final/2009/339089.pdf

Srinivasan, S. 2005. Consequences of financial reporting failure for outside directors: Evidence from accounting restatements and audit committee members. Journal of Accounting Research 43: 291-334.

Steinberg, R. 2011. What’s keeping directors up at night? Compliance Week, April 19.

Teoh, S., Welch, I., Wong, T. 1998. Earnings management and the long-run underperformance of seasoned equity offerings. Journal of Financial Economics 50: 63-100.

Yermack, D. 2010. Shareholder voting and corporate governance. Annual Review of Financial Economics 2: 2.1-2.23 


\section{Table 1: Descriptive Statistics}

Panel A: Lawsuit characteristics

\begin{tabular}{lcc}
\hline Means & $\begin{array}{c}\text { Full Sample } \\
(\mathrm{n}=2,516)\end{array}$ & $\begin{array}{c}\text { IRRC } \\
(\mathrm{n}=921)\end{array}$ \\
\hline GAAP Violation Alleged & $46.50 \%$ & $57.55 \%$ \\
Section 11 & $25.28 \%$ & $11.51 \%$ \\
SEC Action & $1.79 \%$ & $3.15 \%$ \\
Backdating of Stock Options & $1.44 \%$ & $4.96 \%$ \\
Institutional Lead Plaintiff & $37.12 \%$ & $53.09 \%$ \\
Class Period Length & 509.8 days & 632.1 days \\
Settled & $61.87 \%$ & $55.00 \%$ \\
Time to Settlement & $1,486.4$ days & $1,273.1$ days \\
Settlement Amount (\$) & $\$ 42,806,711$ & $\$ 102,499,675$ \\
Settlement Amount (\% of Total Assets) & $3.96 \%$ & $1.85 \%$ \\
\# Directors Named & N/A & 0.89 \\
\hline
\end{tabular}

Panel B: Director characteristics

\begin{tabular}{lcccc}
\hline & \multicolumn{2}{c}{$\begin{array}{c}\text { Lawsuit firms }(\mathrm{n}=5,461) \\
\text { Mean }\end{array}$} & \multicolumn{2}{c}{ Matched firms (n=4,739) } \\
Median & Mean & Median \\
\hline Named in Lawsuit & 0.11 & 0.00 & - & - \\
Shares Held (\%) & 0.17 & 0.01 & 0.15 & $0.01^{* * *}$ \\
Sold Shares Indicator & 0.11 & 0.00 & $0.09^{* * *}$ & $0.00^{* * *}$ \\
Shares Sold (\%) & 3.50 & 0.00 & $0.19^{* * *}$ & $0.00^{* * *}$ \\
Audit Committee & 0.49 & 0.00 & 0.51 & 1.00 \\
Director Age & 60.55 & 61.00 & 60.57 & 61.00 \\
Age 65 & 0.29 & 0.00 & 0.28 & 0.00 \\
Female & 0.15 & 0.00 & 0.14 & 0.00 \\
On Board During Full Class Period & 0.76 & 1.00 & 0.73 & 1.00 \\
Tenure & 6.78 & 5.00 & 6.59 & 5.00 \\
New Director & 0.17 & 0.00 & $0.20^{* * * *}$ & $0.00^{* * *}$ \\
\# Other Boards & 1.19 & 1.00 & 1.17 & 1.00 \\
\hline
\end{tabular}

Panel C: Firm characteristics

\begin{tabular}{lcccc}
\hline & \multicolumn{2}{c}{ Lawsuit firms $(\mathrm{n}=805)$} & \multicolumn{2}{c}{ Matched firms (n=805) } \\
& Mean & Median & Mean & Median \\
\hline Class Period Price Drop & 0.39 & 0.44 & 0.36 & $0.39^{* * *}$ \\
Share Turnover (\%) & 1.27 & 0.97 & $1.04^{* * *}$ & $0.85^{* * *}$ \\
Equity Issuance & 0.13 & 0.00 & 0.12 & 0.00 \\
ROA & -0.02 & 0.02 & -0.01 & 0.02 \\
Firm Size & 14.48 & 14.57 & 14.45 & 14.64 \\
Sales Growth & 0.11 & 0.04 & 0.09 & 0.04 \\
High Litigation Risk Industry & 0.38 & 0.00 & 0.34 & 0.00 \\
Board Size & 9.48 & 9.00 & 9.67 & 9.00 \\
\hline
\end{tabular}

$* * *, * *, *$ indicate that the matched firm mean or median is significantly different from the lawsuit firm mean or median at the $0.01,0.05,0.10$ levels, respectively. 


\section{Table 1 (cont.)}

Table 1 reports descriptive statistics for our main analyses. The sample consists of Section 10b5 and 11 securities lawsuits filed between 1996 and 2010.

Panel A compares the full sample of lawsuits from the ISS database to the subset matched with firms in the IRRC database. GAAP Violation Alleged indicates lawsuits that allege violation of U.S. GAAP. Section 11 indicates lawsuits filed under Section 11 of the Securities Act of 1933. SEC Action indicates lawsuits where there is a related SEC action. Backdating of Stock Options indicates lawsuits that pertain to employee stock option backdating. Institutional Lead Plaintiff indicates lawsuits where the lead plaintiff is an institutional investor. Class Period Length is the number of days between the beginning and the end of the class period. Settled indicates lawsuits that are not dismissed and reach a settlement. Time to Settlement is the number of days between the lawsuit filing date and the date a settlement is reached, if any. Settlement Amount (\$) is the total dollar amount of settlement for settled cases. Settlement Amount (\% of Total Assets) is the total dollar amount of settlement for settled cases, divided by total assets as of the most recent fiscal year preceding the lawsuit filing. \# Directors Named is the number of independent directors named as defendants in a lawsuit.

Panel B reports descriptive statistics for director-level variables, where all independent directors who were on the board of an IRRC firm subject to a securities lawsuit at the time of the lawsuit filing date are included. Named in Lawsuit indicates an independent director who is named as defendant in the lawsuit. Shares Held is the director's stock holdings as a percentage of shares outstanding as of the latest annual meeting prior to the lawsuit filing date. Sold Shares Indicator indicates a director who sold shares during the class period. Shares Sold is the number of shares sold by a director during the class period as a percentage of their stock holdings. Audit Committee indicates a director who is member of the audit committee. Director Age is a director's age as of the lawsuit filing date. Age 65 indicates directors who are older than 65 as of the lawsuit filing date. Female indicates a female director. On Board During Full Class Period indicates that a director was on the board before the start of the class period. Tenure indicates the number of years the director has been on the litigated firm's board as of the lawsuit filing date. New Director indicates that a director has been on the board for a year or less. \# Other Boards is the number of other boards (within IRRC) that the director sits on in the year during which the lawsuit is filed.

Panel C reports descriptive statistics for firm-level variables in the sample of IRRC firms subject to a securities lawsuit. Class Period Price Drop is the difference between the highest stock price during the class period and the stock price as of the end of the lawsuit filing date, scaled by the highest stock price. Share Turnover is the average daily trading volume as a percentage of shares outstanding during the class period (adjusted for NASDAQ firms according to Gao and Ritter 2010). Equity Issuance indicates firms that issued common shares during the class period. ROA is operating income divided by beginning total assets for the fiscal year during which the lawsuit is filed. Firm Size is the log of market capitalization as of the beginning of the fiscal year during which the lawsuit is filed. Sales Growth is the percentage growth in revenue over the fiscal year during which the lawsuit is filed. High Litigation Risk Industry indicates firms in the following SIC groups (as per Francis, Philbrick and Schipper 1994): 2833-2836, 3570-3577, 3600-3674, 5200-5961, 7370-7374, 8731-8734. Board Size is the number of directors on the board as of the latest annual meeting preceding the lawsuit filing date. 
Table 2: Determinants of directors being named as defendants - Univariate analysis

\begin{tabular}{lccc}
\hline & $\begin{array}{c}\text { Directors } \\
\text { Named } \\
\text { Defendants } \\
(1)\end{array}$ & $\begin{array}{c}\text { Directors not } \\
\text { Named } \\
\text { Defendants }\end{array}$ & $\begin{array}{c}\text { t-stat for } \\
(1)-(2)\end{array}$ \\
\hline Shares Held (\%) & 0.14 & 0.16 & -0.47 \\
Sold Shares Indicator & 0.16 & 0.11 & $3.14 * * *$ \\
Shares Sold (\%) & 4.99 & 3.22 & $2.62 * * *$ \\
Audit Committee & 0.54 & 0.49 & $2.10 * *$ \\
Director Age & 61.50 & 60.42 & $3.03 * * *$ \\
Female & 0.12 & 0.15 & $-2.04 * *$ \\
On Board During Full Class Period & 0.86 & 0.74 & $7.36 * * *$ \\
Tenure & 7.55 & 6.68 & $3.52 * * *$ \\
\# Other Boards & 1.20 & 1.18 & 0.45 \\
\hline
\end{tabular}

Table 2 reports univariate analyses of the determinants of independent board directors being named as defendants in a sample of 805 Section $10 \mathrm{~b} 5$ or 11 lawsuits filed between 1996 and 2010 against firms in the IRRC database. The sample includes all independent directors who are on the board of a sued firm at the time the lawsuit is filed. The table reports univariate comparisons of director characteristics for named directors (Column 1), and their non-named counterparts in all sued firms in the sample (Column 2). Director characteristics are defined in the notes from Table $1 . * * *, * *, *$ indicate significance at the $0.01,0.05,0.10$ levels, respectively. 
Table 3: Determinants of directors being named as defendants - Logistic analysis

\begin{tabular}{|c|c|c|c|}
\hline & \multicolumn{3}{|c|}{ Full sample } \\
\hline & Marginal & effect & z-stat \\
\hline \multicolumn{4}{|l|}{ Director characteristics } \\
\hline Shares Held (\%) & -6.48 & & -0.30 \\
\hline Shares Sold & 5.69 & $* *$ & 2.29 \\
\hline Audit Committee & 1.23 & $* *$ & 2.37 \\
\hline Director Age & -0.01 & & -0.17 \\
\hline Female & -0.42 & & -0.65 \\
\hline On Board During Full Class Period & 4.48 & $* * *$ & 3.17 \\
\hline Tenure & 0.06 & & 1.03 \\
\hline \# Other Boards & 0.35 & & 1.32 \\
\hline \multicolumn{4}{|l|}{ Lawsuit characteristics } \\
\hline GAAP Violation Alleged & 1.53 & & 0.98 \\
\hline Section 11 & 11.36 & $* * *$ & 5.44 \\
\hline SEC Action & -10.59 & $*$ & -1.80 \\
\hline Backdating of Stock Options & 11.88 & $* * *$ & 3.41 \\
\hline Institutional Lead Plaintiff & 3.15 & $* *$ & 2.06 \\
\hline Log Class Period & -1.35 & $* *$ & -2.15 \\
\hline \multicolumn{4}{|l|}{ Firm characteristics } \\
\hline Class Period Price Drop & -1.01 & & -0.94 \\
\hline Share Turnover (\%) & 1.96 & $* * *$ & 3.47 \\
\hline Equity Issuance & 4.49 & $* *$ & 2.47 \\
\hline ROA & -3.00 & $* * *$ & -2.66 \\
\hline Firm Size & 0.54 & & 1.05 \\
\hline Sales Growth & 0.04 & & 0.02 \\
\hline High Litigation Risk Industry & -1.78 & & -1.13 \\
\hline Board Size & -0.39 & & -1.36 \\
\hline Time & 3.98 & & 0.59 \\
\hline $\mathrm{N}$ & 5,400 & & \\
\hline Pseudo $\mathrm{R}^{2}$ & $28.71 \%$ & & \\
\hline Fixed effects & Year anc & d Feder & Court \\
\hline
\end{tabular}

Table 3 reports results from a logistic regression for the analysis of determinants of independent board directors being named as defendants in a sample of 805 Section $10 \mathrm{~b} 5$ and 11 securities lawsuits filed between 1996 and 2010 against firms in the IRRC database. Units of observations are pairs of firms and directors. Directors are included if they are on the board of a sued firm at the time the lawsuit is filed. The dependent variable is equal to one if a director is named as defendant in the lawsuit and zero otherwise. The complete set of independent variables is defined in the notes from Table 1 . Reported marginal effects are multiplied by 100 . ***,**** indicate significance at the $0.01,0.05,0.10$ levels, respectively. Standard errors are clustered by firm and director. 
Table 4: ISS recommendation, shareholder voting and director turnover in sued firms - Univariate analysis

\begin{tabular}{|c|c|c|c|c|c|c|}
\hline & $\begin{array}{l}\text { Not Named in } \\
\text { Lawsuit } \\
\text { (1) }\end{array}$ & $\begin{array}{c}\text { T-stat } \\
(2)-(1)\end{array}$ & $\begin{array}{l}\text { Named in } \\
\text { Lawsuit } \\
\text { (2) }\end{array}$ & $\begin{array}{c}T \text {-stat } \\
(2)-(3)\end{array}$ & $\begin{array}{c}\text { Director of } \\
\text { Matched Firm } \\
\text { (3) }\end{array}$ & $\begin{array}{c}\text { T-stat } \\
(1)-(3)\end{array}$ \\
\hline ISS “Withhold” recommendations & 7.29 & $3.12 * * *$ & 23.88 & $3.43 * * *$ & 5.78 & 1.49 \\
\hline Shareholder votes withheld & 6.13 & $3.22 * * *$ & 10.50 & $4.07 * * *$ & 5.03 & $3.71 * * *$ \\
\hline Director turnover & 13.31 & $3.29 * * *$ & 22.36 & $2.60 * * *$ & 15.23 & $-2.02 * *$ \\
\hline
\end{tabular}

Table 4 reports univariate analyses of proxy advisory firm ISS recommendations, shareholder voting and director turnover for independent board directors. ISS recommendations and shareholder voting are for a sample of 237 Section 10b-5 or 11 lawsuits filed between 2001 and 2008 against firms in the IRRC database and director turnover is for a sample of 423 Section $10 \mathrm{~b} 5$ or 11 lawsuits filed between 1996 and 2008 against firms in the IRRC.

The sample includes three groups of independent directors: Named in Lawsuit (Not Named in Lawsuit) indicates that a director is on the board of a sued firm at the time the lawsuit is filed and is (not) named as a defendant in the lawsuit; Director of Matched Firm indicates that a director is on the board of a non-sued firm matched with a sued firm by year, industry, ROA and estimated litigation risk, based on the Rogers and Stocken (2005) model. ISS "Withhold" recommendations indicate director elections for which ISS recommends that shareholders do not vote in favor of a director. Shareholder votes withheld measure mean votes withheld scaled by votes cast for director elections within two years of the lawsuit filing date (only the first recommendation/vote is included for each director). A director is considered to have turned over if they are no longer on the board within two years of the lawsuit filing.

All numbers are expressed in percentages. ***,**,* indicate significance at the $0.01,0.05,0.10$ levels, respectively. 


\section{Table 5: Shareholder voting in sued firms - Regression analysis}

Panel A: Effect of being named as defendant

\begin{tabular}{|c|c|c|c|c|c|}
\hline & \multicolumn{3}{|c|}{$\begin{array}{c}\text { Logit } \\
\text { ISS “Withhold" } \\
\text { Recommendation }\end{array}$} & \multicolumn{2}{|c|}{$\begin{array}{c}\text { OLS } \\
\text { Shareholder Votes } \\
\text { Withheld }\end{array}$} \\
\hline & \multicolumn{2}{|c|}{ Marginal Effect } & \multirow[t]{2}{*}{ Z stat } & Coefficient & \multirow[t]{2}{*}{ T-stat } \\
\hline Director characteristics & & & & & \\
\hline Named in Lawsuit & 6.40 & $* *$ & 2.39 & $4.24 * * *$ & 2.64 \\
\hline Shares Held (\%) & 0.47 & & 0.89 & 0.35 & 1.07 \\
\hline Shares Sold & -7.07 & & -1.48 & -1.86 & -0.86 \\
\hline Audit Committee & -0.02 & & -0.02 & -0.18 & -0.33 \\
\hline Age 65 & 2.35 & & 1.56 & -0.14 & -0.22 \\
\hline Female & 1.54 & & 0.89 & 0.51 & 0.79 \\
\hline New Director & -1.06 & & -0.49 & $-1.87^{* *}$ & -2.18 \\
\hline Tenure & -0.24 & & -1.59 & 0.00 & 0.17 \\
\hline \# Other Boards & -0.05 & & -0.11 & 0.18 & 0.90 \\
\hline \multicolumn{6}{|l|}{ Lawsuit characteristics } \\
\hline GAAP Violation Alleged & 1.96 & & 1.31 & $1.28^{* *}$ & 2.08 \\
\hline Section 11 & 5.30 & $* *$ & 2.42 & $2.63^{* * *}$ & 2.81 \\
\hline SEC Action & -14.88 & & -1.48 & 0.99 & 0.73 \\
\hline Backdating of Stock Options & -5.13 & & -1.47 & -3.16 & -1.15 \\
\hline Institutional Lead Plaintiff & 1.03 & & 0.68 & -0.07 & -0.12 \\
\hline Log Class Period & -0.02 & & -0.04 & -0.06 & -0.27 \\
\hline Settled & -3.77 & $* * *$ & -2.69 & -0.31 & -0.60 \\
\hline \multicolumn{6}{|l|}{ Firm characteristics } \\
\hline Class Period Price Drop & 6.80 & $* * *$ & 1.99 & 0.47 & 0.36 \\
\hline Share Turnover (\%) & 1.99 & $* *$ & 2.38 & $1.92^{* * *}$ & 3.43 \\
\hline Equity Issuance & 1.40 & & 0.70 & $-1.32 *$ & -1.90 \\
\hline ROA & 8.50 & & 1.39 & -2.49 & -1.09 \\
\hline Firm Size & 1.47 & $* * *$ & 2.68 & $1.09^{* * *}$ & 5.09 \\
\hline Sales Growth & -0.36 & & -0.14 & -0.03 & 0.05 \\
\hline High Litigation Risk Industry & 4.69 & $* * *$ & 2.80 & $1.66^{* *}$ & 2.51 \\
\hline Board Size & -0.67 & $* *$ & -2.02 & $-0.19^{* *}$ & -1.97 \\
\hline $\mathrm{N}$ & 1,047 & & & 1,026 & \\
\hline Pseudo $\mathrm{R}^{2}$ / Adj. $\mathrm{R}^{2}$ & $15.93 \%$ & & & $18.24 \%$ & \\
\hline Fixed effects & \multicolumn{3}{|c|}{ Year } & \multicolumn{2}{|l|}{ Year } \\
\hline
\end{tabular}


Table 5 (cont.)

Panel B: Dismissed versus settled cases

Logit OLS

ISS "Withhold"

Recommendation

Shareholder Votes

\begin{tabular}{lcccc} 
& \multicolumn{3}{c}{ Recommendation } & \multicolumn{2}{c}{ Withheld } \\
\hline & Marginal Effect & Z stat & Coefficient & T stat \\
\hline Settled $\left(\mathrm{b}_{1}\right)$ & $-2.82^{*}$ & -1.71 & -0.23 & -0.42 \\
Named in Lawsuit $\left(\mathrm{b}_{2}\right)$ & $10.51^{*}$ & 1.87 & $4.777^{* * *}$ & 2.58 \\
Named in Lawsuit $\times$ Settled $\left(\mathrm{b}_{3}\right)$ & 0.60 & 0.02 & -1.22 & -0.53 \\
\hline Controls & Included & \multicolumn{3}{c}{ Included } \\
Pseudo $\mathrm{R}^{2} /$ Adj. $\mathrm{R}^{2}$ & $16.02 \%$ & & $18.22 \%$ & \\
\hline F-test $\left(\right.$ Named \& Settled) $\left[\mathrm{b}_{2}+\mathrm{b}_{3}=0\right]$ & $4.58^{* *}$ & & 2.75 & \\
\end{tabular}

Panel C: Audit committee members versus others

\begin{tabular}{|c|c|c|c|c|}
\hline & \multicolumn{2}{|c|}{$\begin{array}{c}\text { Logit } \\
\text { ISS “Withhold” } \\
\text { Recommendation }\end{array}$} & \multicolumn{2}{|c|}{$\begin{array}{c}\text { OLS } \\
\text { Shareholder Votes } \\
\text { Withheld }\end{array}$} \\
\hline & $\begin{array}{c}\text { Marginal } \\
\text { Effect }\end{array}$ & Z stat & Coefficient & T stat \\
\hline Audit Committee $\left(\mathrm{b}_{1}\right)$ & -0.07 & -0.05 & -0.13 & -0.25 \\
\hline Named in Lawsuit $\left(\mathrm{b}_{2}\right)$ & 6.24 & 1.53 & $4.71^{* *}$ & 2.20 \\
\hline Named in Lawsuit $\times$ Audit Committee $\left(b_{3}\right)$ & 1.93 & 0.18 & -0.77 & -0.29 \\
\hline Controls & Included & & Included & \\
\hline Pseudo $\mathrm{R}^{2} /$ Adj. $\mathrm{R}^{2}$ & $15.93 \%$ & & $18.25 \%$ & \\
\hline F-test (Named \& Audit Committee) $\left[\mathrm{b}_{2}+\mathrm{b}_{3}=0\right]$ & $7.61^{* * *}$ & & $3.87^{* * *}$ & \\
\hline
\end{tabular}




\section{Table 5 (cont.)}

Table 5 reports regression results for the analysis of proxy advisory firm ISS recommendations and shareholder voting for director elections in a sample of 237 Section 10b5 or 11 lawsuits filed between 2001 and 2008 against firms in the IRRC database. In Panels A, B and C, the sample includes all independent directors who are on the board of a sued firm at the time the lawsuit is filed. For the proxy advisory firm recommendation analysis, the model specification is logistic and the dependent variable is equal to one if ISS recommends that shareholders do not vote in favor of a director for his/her election, and zero otherwise. Marginal effects are reported. In Panels B and C, the marginal effects of interaction terms are adjusted based on Ai and Norton (2003), and the F-tests are based on sums of coefficients and coefficient differences. For the shareholder voting analysis, the model specification is OLS and the dependent variable is the percentage of votes withheld scaled by votes cast for director elections within two years of the lawsuit filing date. In both models, only the first recommendation/vote is included for each director. Reported marginal effects and OLS coefficients are multiplied by 100. Named in Lawsuit indicates an independent director who is on the board of a firm subject to a securities lawsuit, and who is named as defendant in the lawsuit. All other independent variables are defined in the notes from Table $1 .{ }^{* * *}, * * * *$ indicate significance at the 0.01, 0.05, 0.10 levels, respectively. Standard errors are clustered by firm and director. 
Table 6: Shareholder voting in sued and matched firms - Regression analysis

Panel A: Effect of being named as defendant

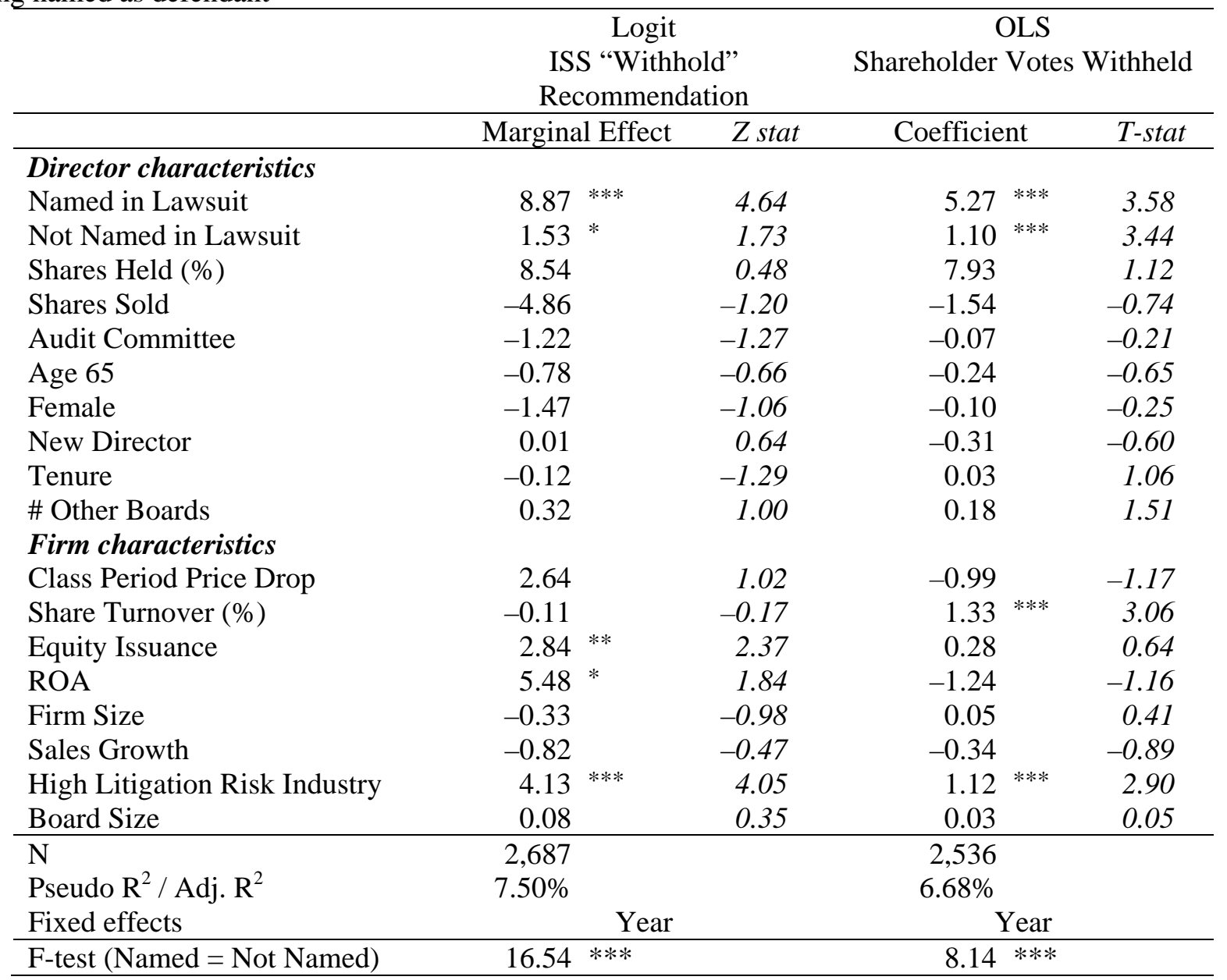


Table 6 (cont.)

Panel B: Dismissed versus settled cases

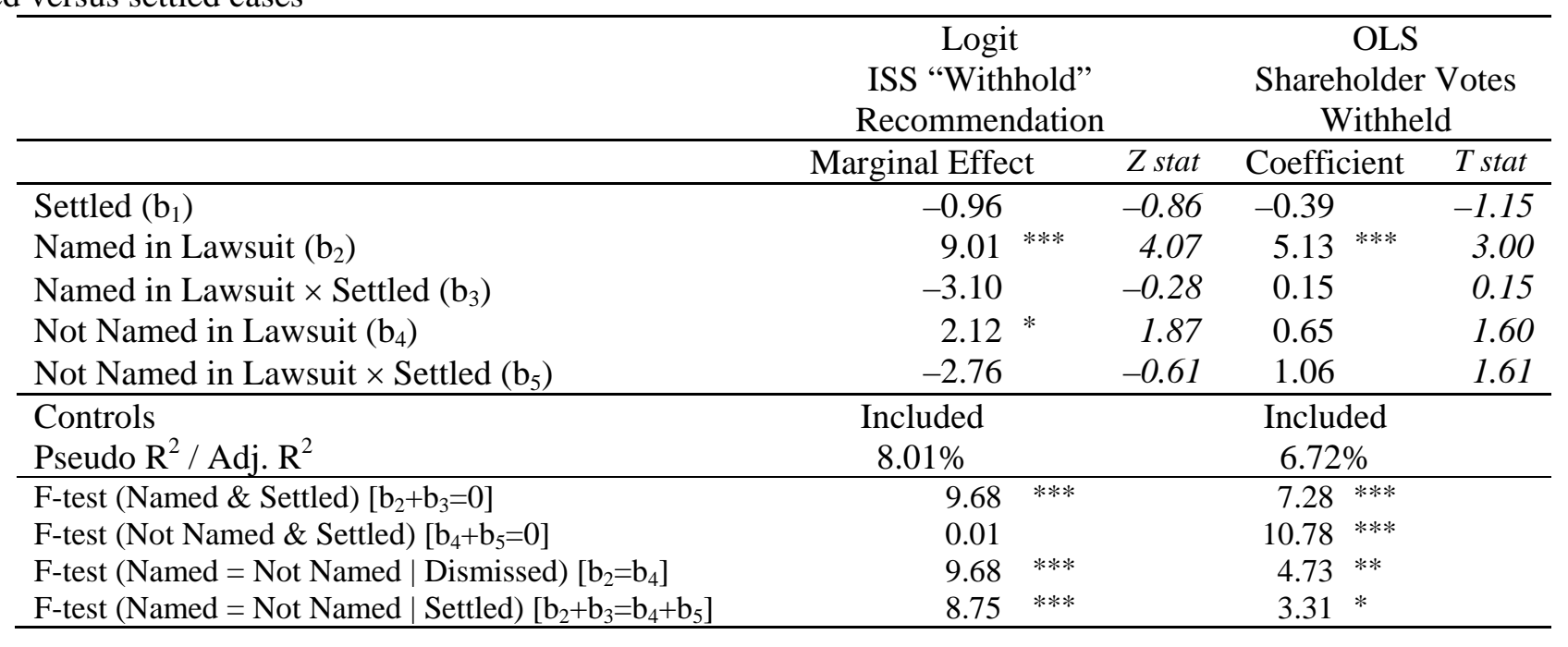


Table 6 (cont.)

Panel C: Audit committee members versus others

\begin{tabular}{|c|c|c|c|c|}
\hline & \multicolumn{2}{|c|}{$\begin{array}{c}\text { Logit } \\
\text { ISS "Withhold" } \\
\text { Recommendation }\end{array}$} & \multicolumn{2}{|c|}{$\begin{array}{c}\text { OLS } \\
\text { Shareholder Votes } \\
\text { Withheld }\end{array}$} \\
\hline & Marginal Effect & Z stat & Coefficient & T stat \\
\hline Audit Committee $\left(\mathrm{b}_{1}\right)$ & $-2.45 *$ & -1.77 & -0.11 & -0.28 \\
\hline Named in Lawsuit $\left(b_{2}\right)$ & $5.68 *$ & 1.78 & $4.91^{* * *}$ & 2.62 \\
\hline Named in Lawsuit $\times$ Audit Committee $\left(b_{3}\right)$ & 11.29 & 1.04 & 0.59 & 0.24 \\
\hline Not Named in Lawsuit $\left(\mathrm{b}_{4}\right)$ & 0.47 & 0.37 & $1.06^{* *}$ & 2.08 \\
\hline Not Named in Lawsuit $\times$ Audit Committee $\left(b_{5}\right)$ & 2.30 & 0.46 & 0.07 & 0.10 \\
\hline $\begin{array}{l}\text { Controls } \\
\text { Pseudo } \mathrm{R}^{2} \text { / Adj. } \mathrm{R}^{2}\end{array}$ & $\begin{array}{c}\text { Included } \\
7.73 \%\end{array}$ & & $\begin{array}{l}\text { Included } \\
6.68 \%\end{array}$ & \\
\hline F-test (Named \& Audit Committee) $\left[\mathrm{b}_{2}+\mathrm{b}_{3}=0\right]$ & $24.95^{* * *}$ & & $8.05^{* * *}$ & \\
\hline F-test (Not Named \& Audit Committee) $\left[b_{4}+b_{5}=0\right]$ & $4.09 * *$ & & $6.31 * *$ & \\
\hline F-test (Named = Not Named | Not Audit Committee) $\left[b_{2}=b_{4}\right]$ & $2.74 *$ & & $5.62 * *$ & \\
\hline F-test (Named $=$ Not Named $\mid$ Audit Committee) $\left[b_{2}+b_{3}=b_{4}+b_{5}\right]$ & $16.05^{* * *}$ & & $5.15^{* *}$ & \\
\hline
\end{tabular}

Table 6 reports regression results for the analysis of proxy advisory firm ISS recommendations and shareholder voting for director elections in a sample of 237 Section 10b5 or 11 lawsuits filed between 2001 and 2008 against firms in the IRRC database. In Panels A, B and C, the sample includes all independent directors who are on the board of a sued firm at the time the lawsuit is filed, and independent directors of non-sued firms matched with sued firms by year, industry, ROA and estimated litigation risk, based on the Rogers and Stocken (2005) model. For the proxy advisory firm recommendation analysis, the model specification is logistic and the dependent variable is equal to one if ISS recommends that shareholders do not vote in favor of a director for his/her election, and zero otherwise. Marginal effects are reported. In Panel A, F (Named=Not Named) reports F values for tests of coefficient differences between Named in Lawsuit and Not Named in Lawsuit.

In Panels B and C, the marginal effects of interaction terms are adjusted based on Ai and Norton (2003), and the F-tests are based on sums of coefficients and coefficient differences. For the shareholder voting analysis, the model specification is OLS and the dependent variable is the percentage of votes withheld scaled by votes cast for director elections within two years of the lawsuit filing date. In both models, only the first recommendation/vote is included for each director. Reported marginal effects and OLS coefficients are multiplied by 100. Named in Lawsuit indicates an independent director who is on the board of a firm subject to a securities lawsuit, and who is named as defendant in the lawsuit. Not Named in Lawsuit indicates an independent director who is on the board of a firm subject to a securities lawsuit, but who is not named as defendant. All other independent variables are defined in the notes from Table $1 .{ }^{* *}, * *, *$ indicate significance at the $0.01,0.05,0.10$ levels, respectively. Standard errors are clustered by firm and director. 
Table 7: Director turnover in sued and matched firms - Regression analysis

Panel A: Effect of being named as defendant

\begin{tabular}{|c|c|c|c|c|c|}
\hline & \multicolumn{2}{|c|}{ Only Lawsuits } & \multicolumn{3}{|c|}{ Lawsuits and Matches } \\
\hline & Marginal Effect & \multirow[t]{2}{*}{ Z stat } & \multicolumn{2}{|c|}{ Marginal Effect } & \multirow[t]{2}{*}{ Z-stat } \\
\hline Director characteristics & & & & & \\
\hline Named in Lawsuit & $4.70^{* *}$ & 2.47 & 3.62 & $*$ & 1.86 \\
\hline Not Named in Lawsuit & & & -2.07 & $* *$ & -1.98 \\
\hline Shares Held (\%) & 9.97 & 0.11 & -12.06 & & -0.22 \\
\hline Shares Sold & $-7.30 *$ & -1.80 & -3.96 & & -0.97 \\
\hline Audit Committee & 0.04 & 0.03 & -1.89 & $*$ & -1.86 \\
\hline Age 65 & $7.22^{* * *}$ & 5.53 & 9.59 & $* * *$ & 8.05 \\
\hline Female & 2.24 & 1.27 & 2.10 & & 1.40 \\
\hline Tenure & -0.05 & -0.49 & 0.00 & & 0.06 \\
\hline \# Other Boards & 0.17 & 0.38 & -0.79 & * & -1.85 \\
\hline \multicolumn{6}{|l|}{ Lawsuit characteristics } \\
\hline GAAP violation alleged & -0.54 & -0.40 & & & \\
\hline Section 11 & $4.42^{* *}$ & 2.16 & & & \\
\hline SEC Action & 0.54 & 0.17 & & & \\
\hline Backdating of stock options & 2.21 & 0.48 & & & \\
\hline Institutional Lead Plaintiff & 0.65 & 0.46 & & & \\
\hline Log Class Period & $1.27^{* * *}$ & 2.61 & & & \\
\hline Settled & -0.06 & -0.04 & & & \\
\hline \multicolumn{6}{|l|}{ Firm characteristics } \\
\hline Class Period Price Drop & -0.21 & -0.08 & 1.86 & & 0.98 \\
\hline Share Turnover (\%) & $2.28^{* * *}$ & 3.07 & 2.23 & $* * *$ & 3.67 \\
\hline Equity Issuance & $-4.33^{* *}$ & -2.16 & -3.46 & $* *$ & -2.42 \\
\hline $\mathrm{ROA}$ & -0.02 & -0.01 & -2.89 & * & -1.77 \\
\hline Firm Size & 0.27 & 0.57 & 0.61 & * & 1.67 \\
\hline Sales Growth & -0.68 & -0.38 & -3.00 & * & -1.69 \\
\hline High Litigation Risk Industry & $-2.53 *$ & -1.67 & -3.69 & $* * *$ & -3.06 \\
\hline Board Size & 0.08 & 0.28 & 0.29 & & 1.58 \\
\hline $\mathrm{N}$ & 2,600 & & 5,525 & & \\
\hline Pseudo $\mathrm{R}^{2}$ & $9.72 \%$ & & $7.43 \%$ & & \\
\hline Fixed effects & \multicolumn{2}{|l|}{ Year } & \multicolumn{3}{|c|}{ Year } \\
\hline F-test (Named= Not Named) & & & 9.34 & $* * *$ & \\
\hline
\end{tabular}


Table 7 (Cont.)

Panel B: Dismissed versus settled cases

\begin{tabular}{|c|c|c|c|c|}
\hline & $\begin{array}{l}\text { Only Lawsuits } \\
\text { Marginal Effect }\end{array}$ & Z stat & $\begin{array}{c}\text { Lawsuits \& Matches } \\
\text { Marginal Effect }\end{array}$ & $\bar{Z}$ stat \\
\hline Settled $\left(b_{1}\right)$ & -0.86 & -0.57 & 1.07 & 0.98 \\
\hline Named in Lawsuit $\left(b_{2}\right)$ & -2.31 & -0.49 & -5.87 & -1.20 \\
\hline Named in Lawsuit $\times$ Settled $\left(b_{3}\right)$ & $11.76 *$ & 1.87 & $13.78^{* *}$ & 2.48 \\
\hline Not Named in Lawsuit $\left(\mathrm{b}_{4}\right)$ & & & -1.54 & -1.03 \\
\hline Not Named in Lawsuit $\times$ Settled $\left(b_{5}\right)$ & & & -1.82 & -0.34 \\
\hline Controls & Included & & Included & \\
\hline Pseudo $\mathrm{R}^{2}$ / Adj. $\mathrm{R}^{2}$ & $9.90 \%$ & & $7.58 \%$ & \\
\hline F-test (Named \& Settled) $\left[\mathrm{b}_{2}+\mathrm{b}_{3}=0\right]$ & $9.86^{* * *}$ & & $7.04^{* * *}$ & \\
\hline F-test (Not Named \& Settled) $\left[b_{4}+b_{5}=0\right]$ & & & $4.40^{* *}$ & \\
\hline F-test (Named $=$ Not Named $\mid$ Dismissed) $\left[b_{2}=b_{4}\right]$ & & & 0.80 & \\
\hline F-test $\left(\right.$ Named $=$ Not Named | Settled) $\left[b_{2}+b_{3}=b_{4}+b_{5}\right]$ & & & $15.79^{* * *}$ & \\
\hline
\end{tabular}

Panel C: Audit committee members versus others

\begin{tabular}{|c|c|c|c|c|}
\hline & $\begin{array}{l}\text { Only Lawsuits } \\
\text { Marginal Effect }\end{array}$ & Z stat & $\begin{array}{c}\text { Lawsuits \& } \\
\text { Matches } \\
\text { Marginal Effect }\end{array}$ & Z stat \\
\hline Audit Committee $\left(\mathrm{b}_{1}\right)$ & -0.42 & -0.32 & $-4.09^{* *}$ & -2.41 \\
\hline Named in Lawsuit $\left(\mathrm{b}_{2}\right)$ & 2.64 & 0.86 & -0.29 & -0.09 \\
\hline Named in Lawsuit $\times$ Audit Committee $\left(b_{3}\right)$ & 5.44 & 1.03 & 9.12 & 1.64 \\
\hline Not Named in Lawsuit $\left(\mathrm{b}_{4}\right)$ & & & $-4.10^{* *}$ & -2.55 \\
\hline Not Named in Lawsuit $\times$ Audit Committee $\left(b_{5}\right)$ & & & 4.26 & 0.97 \\
\hline Controls & Included & & Included & \\
\hline Pseudo $\mathrm{R}^{2}$ / Adj. $\mathrm{R}^{2}$ & $9.77 \%$ & & $7.58 \%$ & \\
\hline F-test (Named \& Audit Committee) $\left[\mathrm{b}_{2}+\mathrm{b}_{3}=0\right]$ & $7.35^{* * *}$ & & $7.25^{* * *}$ & \\
\hline F-test (Not Named \& Audit Committee) $\left[b_{4}+b_{5}=0\right]$ & & & 0.05 & \\
\hline $\begin{array}{l}\text { F-test (Named = Not Named | Not Audit Committee) } \\
{\left[\mathrm{b}_{2}=\mathrm{b}_{4}\right]}\end{array}$ & & & 1.33 & \\
\hline $\begin{array}{l}\text { F-test (Named }=\text { Not Named } \mid \text { Audit Committee) } \\
{\left[b_{2}+b_{3}=b_{4}+b_{5}\right]}\end{array}$ & & & $8.87^{* * *}$ & \\
\hline
\end{tabular}


Table 7 (Cont.)

Panel D: Pre- and post-2002

\begin{tabular}{|c|c|c|c|c|}
\hline & $\begin{array}{c}\text { Marginal } \\
\text { Effect }\end{array}$ & Z stat & $\begin{array}{c}\text { Marginal } \\
\text { Effect }\end{array}$ & Z stat \\
\hline Post $2002\left(b_{1}\right)$ & $8.63^{* * *}$ & 2.83 & 1.90 & 0.61 \\
\hline Named in Lawsuit $\left(\mathrm{b}_{2}\right)$ & 2.92 & 1.53 & -2.75 & -0.97 \\
\hline Named in Lawsuit $\times$ Post $2002\left(b_{3}\right)$ & 5.69 & 1.04 & $16.92^{* * *}$ & 2.71 \\
\hline Not Named in Lawsuit $\left(\mathrm{b}_{4}\right)$ & & & $-8.466^{* * *}$ & -4.67 \\
\hline Not Named in Lawsuit $\times$ Post $2002\left(b_{5}\right)$ & & & $8.89 *$ & 1.91 \\
\hline Controls & Included & & Included & \\
\hline Pseudo $\mathrm{R}^{2}$ & $9.70 \%$ & & $8.28 \%$ & \\
\hline F-test (Named \& Post 2002) $\left[\mathrm{b}_{2}+\mathrm{b}_{3}=0\right]$ & $5.35^{* *}$ & & $11.51^{* * *}$ & \\
\hline F-test (Not Named \& Post 2002) $\left[b_{4}+b_{5}=0\right]$ & & & 0.91 & \\
\hline F-test $\left(\right.$ Named $=$ Not Named $\mid$ Pre 2002) $\left[b_{2}=b_{4}\right]$ & & & $3.35 *$ & \\
\hline F-test $\left(\right.$ Named $=$ Not Named | Post 2002) $\left[b_{2}+b_{3}=b_{4}+b_{5}\right]$ & & & $9.41^{* * *}$ & \\
\hline
\end{tabular}

Table 7 reports regression results for the analysis of director turnover in a sample of 423 Section $10 \mathrm{~b} 5$ or 11 lawsuits filed between 1996 and 2008 against firms in the IRRC database. The sample includes all independent directors who are on the board of a sued firm at the time the lawsuit is filed, and a control group consisting of independent directors of non-sued firms matched with sued firms by year, industry, ROA and estimated litigation risk, based on the Rogers and Stocken (2005) model. The model specification is logistic and the dependent variable is equal to one if the director leaves the board within two years of the lawsuit filing year, and zero otherwise. Marginal effects are reported. In Panel A, F (Named=Not Named) reports F values for tests of coefficient differences between Named in Lawsuit and Not Named in Lawsuit.

In Panels B, C and D, the marginal effects of interaction terms are adjusted based on Ai and Norton (2003), and the F-tests are based on sums of coefficients and coefficient differences. Named in Lawsuit indicates an independent director who is on the board of a firm subject to a securities lawsuit, and who is named as defendant in the lawsuit. Not Named in Lawsuit indicates an independent director who is on the board of a firm subject to a securities lawsuit, but who is not named as defendant. All other independent variables are defined in the notes from Table 1.

Reported marginal effects are multiplied by 100. In all Panels, ***,**** indicate coefficient significance at the $0.01,0.05,0.10$ levels, respectively. Standard errors are clustered by firm and director. 
Table 8: Shareholder voting and director turnover in other board positions

\begin{tabular}{|c|c|c|c|c|c|c|}
\hline \multirow[b]{3}{*}{ Director characteristics } & \multicolumn{2}{|c|}{$\begin{array}{c}\text { Logit } \\
\text { ISS “Withhold” } \\
\text { Recommendation }\end{array}$} & \multicolumn{2}{|c|}{$\begin{array}{c}\text { OLS } \\
\text { Shareholder Votes Withheld }\end{array}$} & \multicolumn{2}{|c|}{$\begin{array}{c}\text { Logit } \\
\text { Turnover }\end{array}$} \\
\hline & Marginal Effect & \multirow[t]{2}{*}{ Z stat } & Coefficient & \multirow[t]{2}{*}{ T-stat } & Marginal Effect & \multirow[t]{2}{*}{ Z-stat } \\
\hline & & & & & & \\
\hline Named in Lawsuit & 2.83 & 0.88 & 0.53 & 0.49 & $5.88 * *$ & 2.51 \\
\hline Not Named in Lawsuit & -0.80 & -0.51 & 0.39 & 0.75 & $4.12^{* * *}$ & 3.08 \\
\hline Shares Held (\%) & 3.51 & 0.86 & $-0.28 *$ & -1.67 & -0.24 & -0.77 \\
\hline Shares Sold & -9.58 & -1.10 & -1.97 & -1.23 & 4.03 & 0.71 \\
\hline Audit Committee & 0.39 & 0.30 & -0.19 & -0.44 & $-2.63 * *$ & -1.97 \\
\hline Age 65 & 1.55 & 0.83 & 0.90 & 1.26 & 1.26 & 0.84 \\
\hline Female & 0.20 & 0.09 & 0.35 & 0.46 & -1.94 & -0.91 \\
\hline New Director & -1.03 & -0.46 & $-1.45^{* *}$ & -2.51 & & \\
\hline Tenure & $0.18^{*}$ & 1.86 & 0.04 & 0.84 & $0.44^{* * *}$ & 4.43 \\
\hline \# Other Boards & 0.16 & 0.19 & 0.21 & 0.74 & -0.19 & -0.36 \\
\hline \multicolumn{7}{|l|}{ Firm characteristics } \\
\hline Class Period Price Drop & 1.01 & 0.42 & 0.88 & 1.24 & 0.40 & 0.20 \\
\hline Share Turnover (\%) & -0.14 & -0.22 & 0.15 & 0.72 & 0.45 & 0.55 \\
\hline Equity Issuance & 0.80 & 0.42 & 0.57 & 0.58 & 5.80 & 1.59 \\
\hline ROA & $-28.73^{* * *}$ & -2.99 & $-8.08^{* * *}$ & -3.50 & $-14.75^{* *}$ & -2.03 \\
\hline Firm Size & $-1.36^{* *}$ & -2.13 & $-0.57^{* * *}$ & -2.68 & 0.30 & 0.64 \\
\hline Sales Growth & 2.17 & 1.29 & 0.47 & 0.58 & -3.71 & -1.28 \\
\hline High Litigation Risk Industry & $2.51 *$ & 1.69 & $1.26^{* *}$ & 2.30 & -0.48 & -0.28 \\
\hline Board Size & 0.49 & 1.22 & 0.07 & 0.54 & 0.19 & 0.73 \\
\hline $\mathrm{N}$ & 2,371 & & 2,344 & & 5,927 & \\
\hline Pseudo $\mathrm{R}^{2}$ / Adj. $\mathrm{R}^{2}$ & $7.77 \%$ & & $5.34 \%$ & & $3.75 \%$ & \\
\hline Fixed effects & \multicolumn{2}{|l|}{ Year } & \multicolumn{2}{|l|}{ Year } & \multicolumn{2}{|l|}{ Year } \\
\hline F-test (Named = Not Named) & 1.35 & & 0.02 & & 0.57 & \\
\hline
\end{tabular}




\section{Table 8 (cont.)}

Table 8 reports regression analyses of proxy advisory firm ISS recommendations, shareholder voting and director turnover for other board seats held by independent board directors of sued firms and a group of matched directors. ISS recommendations and shareholder voting are for a sample of 237 Section 10b-5 or 11 lawsuits filed between 2001 and 2008 against firms in the IRRC database and director turnover is for a sample of 423 Section 10b5 or 11 lawsuits filed between 1996 and 2008 against firms in the IRRC. The sample also includes other board seats held by directors of non-sued firms matched with sued firms by year, industry, ROA and estimated litigation risk, based on the Rogers and Stocken (2005) model.

For the proxy advisory firm recommendation analysis, the model specification is logistic and the dependent variable is equal to one if ISS recommends that shareholders do not vote in favor of a director for his/her election, and zero otherwise. Marginal effects are reported. For the shareholder voting analysis, the model specification is OLS and the dependent variable is the percentage of votes withheld scaled by votes cast for director elections within two years of the lawsuit filing date. In both models, only the first recommendation/vote is included for each director/seat. For the director turnover analysis, the model specification is logistic and the dependent variable is equal to one if the director leaves the board within two years of the lawsuit filing year, and zero otherwise. Marginal effects are reported.

Named in Lawsuit indicates an independent director who is on the board of a firm subject to a securities lawsuit, and who is named as defendant in the lawsuit. Not Named in Lawsuit indicates an independent director who is on the board of a firm subject to a securities lawsuit, but who is not named as defendant. All other variables are defined in the notes of Table 1. In this table, they are measured in the non-sued firms where directors of sued firms and their matches hold board seats.

F (Named=Not Named) reports F values for tests of coefficient differences between Named in Lawsuit and Not Named in Lawsuit. Reported marginal effects and OLS coefficients are multiplied by $100 . * * *, * * * *$ indicate significance at the $0.01,0.05,0.10$ levels, respectively.

Standard errors are clustered by firm and director. 
Table 9: Lawsuit dismissal, settlement speed and amount - Regression analysis

\begin{tabular}{|c|c|c|c|c|c|c|c|c|}
\hline & \multicolumn{2}{|c|}{ Dismissal - Logistic Model } & \multicolumn{3}{|c|}{ Time to Settlement - Hazard Model } & \multicolumn{3}{|c|}{ Settlement Amount - OLS Model } \\
\hline & Marginal Effect & Z stat & \multicolumn{2}{|c|}{ Coefficient } & Chi Square & \multicolumn{2}{|c|}{ Coefficient } & \multirow{2}{*}{$\frac{T \text { stat }}{2.80}$} \\
\hline \# Directors Named & $-2.75 * *$ & -2.18 & 4.27 & $*$ & 2.77 & 9.07 & $* * *$ & \\
\hline GAAP Violation Alleged & $-10.72 * *$ & -2.37 & 35.37 & $* *$ & 6.26 & 53.82 & $* * *$ & 4.00 \\
\hline Section 11 & $-15.66 *$ & -1.90 & -14.28 & & 0.67 & 49.86 & $* *$ & 2.49 \\
\hline SEC Action & & & 112.29 & $* * *$ & 17.52 & 94.65 & $* * *$ & 3.00 \\
\hline Backdating of Stock Options & -23.22 & -1.42 & 12.17 & & 0.14 & 21.16 & & 0.73 \\
\hline Institutional Lead Plaintiff & $-15.66 * * *$ & -3.54 & -24.92 & * & 3.26 & 80.30 & $* * *$ & 6.37 \\
\hline Equity Issuance & 7.72 & 1.17 & 6.01 & & 0.10 & -50.20 & $*$ & -2.89 \\
\hline Log Class Period & $-4.53 * * *$ & -2.81 & 4.96 & & 0.97 & 35.55 & $* * *$ & 6.81 \\
\hline Class Period Price Drop & 9.81 & 1.46 & 6.87 & & 0.29 & -7.80 & & -0.42 \\
\hline ROA & 6.28 & 0.93 & 12.33 & & 1.76 & -13.77 & & -1.18 \\
\hline Firm Size & $2.80 * *$ & 2.04 & -5.68 & & 2.27 & 33.39 & $* * *$ & 7.55 \\
\hline Sales Growth & 3.26 & 0.56 & 1.04 & & 0.00 & 14.25 & & 0.95 \\
\hline High Litigation Risk Industry & -1.54 & -0.32 & -14.47 & & 0.98 & 13.32 & & 0.95 \\
\hline Board Size & -0.00 & -0.00 & -1.14 & & 0.23 & 3.89 & & 1.61 \\
\hline Share Turnover (\%) & -2.65 & -1.09 & -11.00 & $*$ & 2.84 & 16.63 & $* *$ & 2.35 \\
\hline $\mathrm{N}$ & 837 & & 422 & & & 420 & & \\
\hline Fit & Pseudo $\mathrm{R}^{2}$ : $13.11 \mathrm{C}$ & & Likelihood R & atio: & 20 & Adj. $\mathrm{R}^{2}:$ 63.08\% & & \\
\hline Fixed effects & Year and Federal & & Year and Fed & leral & & Year and Federal & $1 \mathrm{Col}$ & \\
\hline
\end{tabular}

Table 9 reports multivariate regression results for the analysis of dismissal likelihood, time to settlement and settlement amount in a sample of 921 Section $10 \mathrm{~b} 5$ and 11 securities lawsuits filed between 1996 and 2010 against firms in the IRRC database. In the first regression, the model specification is logistic and the dependent variable is equal to one if a lawsuit is dismissed and zero if settled. Marginal effects are reported. The second set of results is based on a Cox proportional hazard model where the dependent variable is the number of days between the lawsuit filing date and its settlement date. Regression coefficients are reported. The third set of results is based on an OLS regression where the dependent variable is the natural logarithm of the total dollar amount of the settlement. OLS coefficients are reported. The first regression excludes lawsuits with SEC enforcement actions, because none of them is dismissed. The second and third regressions include only settled cases. All independent variables are defined in the notes from Table 1 . Reported marginal effects and coefficients are multiplied by $100 .{ }^{* * *}, * *, *$ indicate significance at the $0.01,0.05,0.10$ levels, respectively. All standard errors are robust to heteroskedasticity. 